(^) البحث رقم

\title{
أزمة الهوية في العمارة الاخلية السعودية المعاصرة
}

Identity Crisis in Contemporary Saudi Interior Architecture

$$
\begin{aligned}
& \text { الباحثة } \\
& \text { الدكتورة/ دلال صالح الثمراني }
\end{aligned}
$$

$r \cdot 11$ 


\section{أزمة الهوية في العمارة الداخلية السعودية المعاصرة}

Identity Crisis in Contemporary Saudi Interior Architecture

د/ دلال صالح الثمراني

الملخص:

تحتل قضية الهوية و الحداثة في مجال الفنون و العمارة الداخلية مكاناً منقدماً في

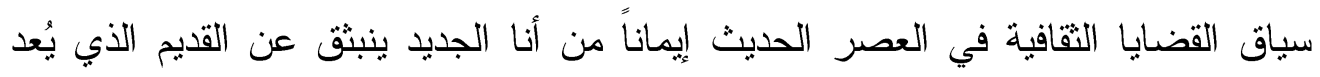
كقاعدة ونقطة انطلاق لبناء الحاضر واستشر اف المستقبل، فالهوية في العمارة الداخلية

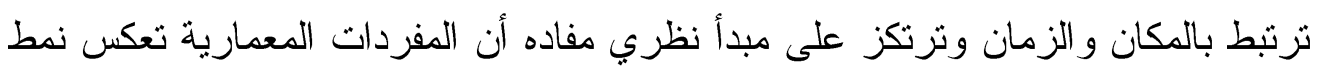

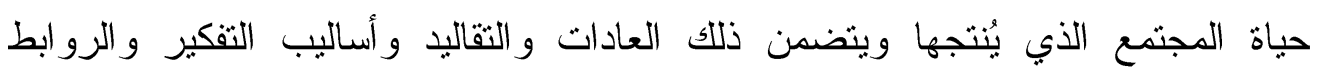

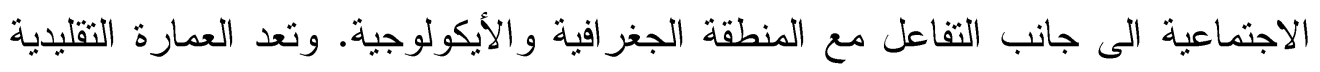

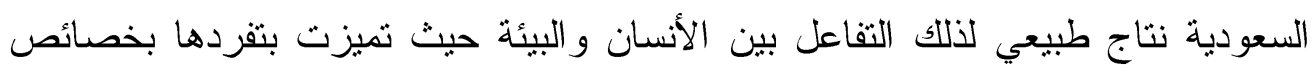

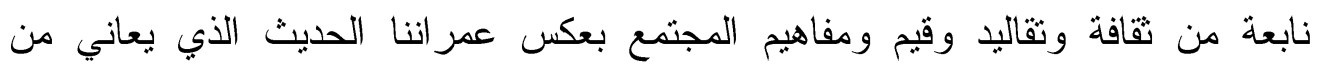

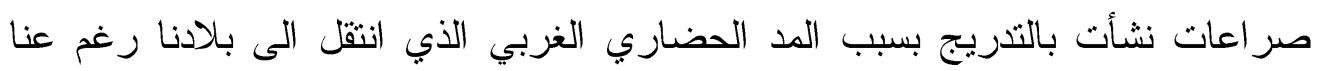

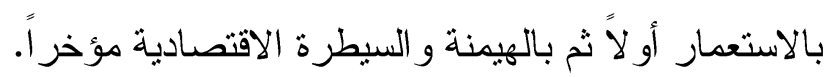
وتُعد التكنولوجيا اليوم إحدى مرنكزات العمارة الداخلية السعودية والتي ساهمت التهن

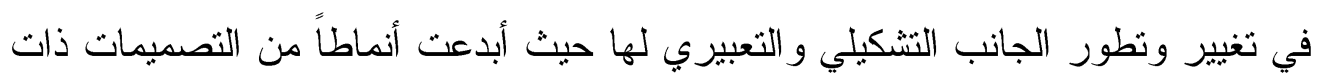
سمة معاصرة حديثة ولكن تفتقد لشيء من التمبز و الخصوصية و الهوية وبالتالي أثرت سلباً

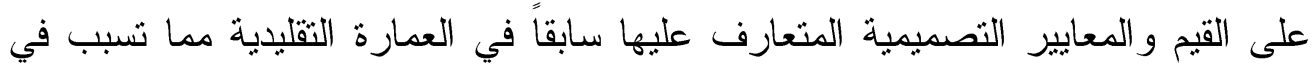
أثنارة الجدل حول الكثير من المفاهيم كالهوية والتراث و الأصالة و المعاصرة. وفي هذهارئ

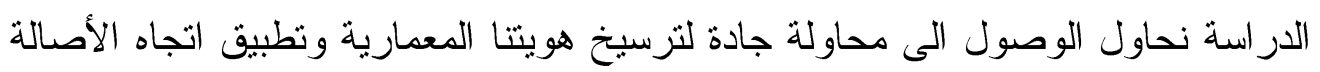

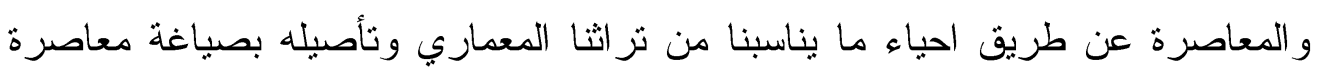
تعتمد على تكنولوجيا منو افقة مع بيئتنا المحلية، وبذلك يهدف هذاء ترنا البحث الى التعريف بالهوية المحلية للعمارة الداخلية السعودية ومميزاتها و الإشكالية التي تو اجهها في التعاطي لبئي مع الهوية المعاصرة. 
الكلمات المفتاحية:

هوية العمارة الداخلية، أزمة الهوية، الأصالة في العمارة الداخلية، المعاصرة، التراث المحلي في العمارة الداخلية.

المقدمة:

الهوية هي مجموعة السمات التي تُميز أنسان أو شعب عن الأخر، وتعد تعبيراً صادقاً عن ثقافتنا المبنية و الفردية الشخصية وتستجيب لاحتياجاتتا حيث تتجلى في أشكال

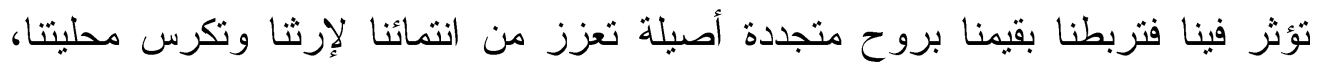

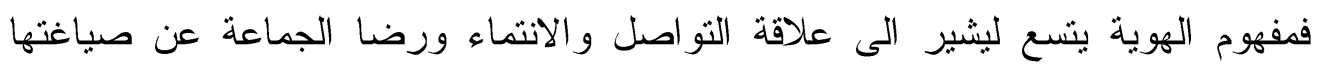
لبيئتها المعمارية والعمر انية. وفي ظل أزمة الهوية التي نعايش سلبياتها اليوم أصبح من لهن

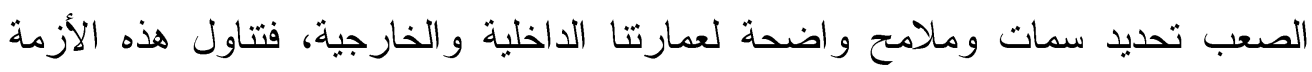

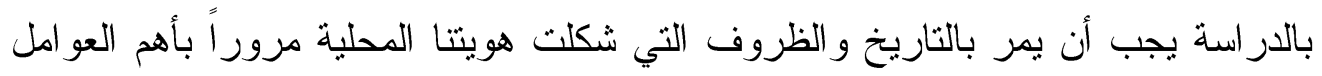

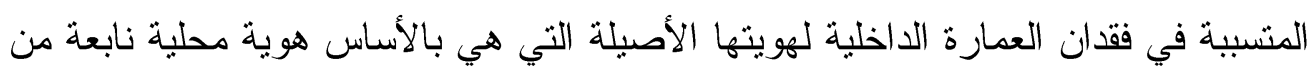
تأثز ها بظروفها الخاصة وصو لاً الى طرق و أساليب تأصيل هذه الهوية في عمارتنا الداخلية

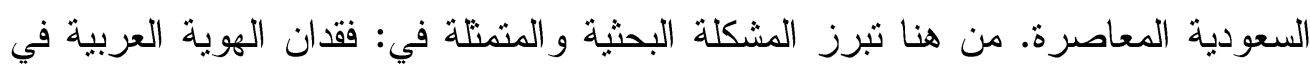

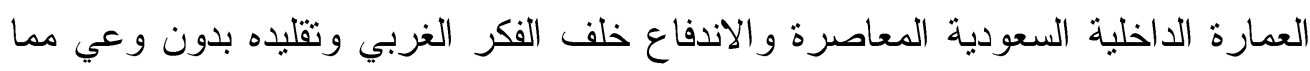

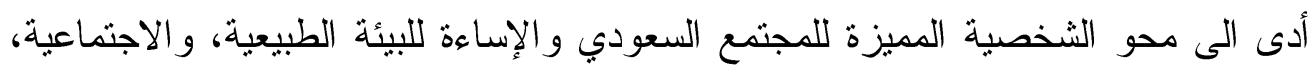

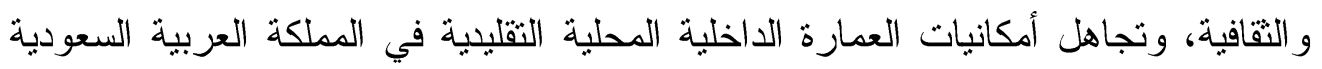

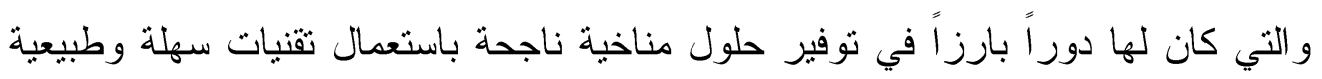

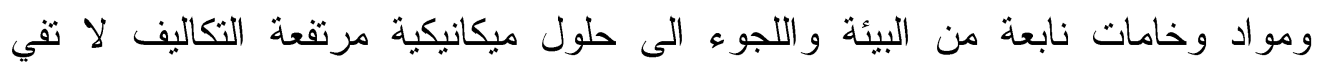
بالمنطلبات البيئية في أغلب الأوقات.

\section{أهداف البحث:}

ا. التأكيد على الهوية المحلية للعمارة الداخلية السعودية وعدم طمسها أو اذابتها فيما

$$
\text { يسمى بالعمارة العالمية. }
$$

r. تأصيل الهوية بالعمارة الداخلية السعودية المعاصرة عن طريق حصر العناصر

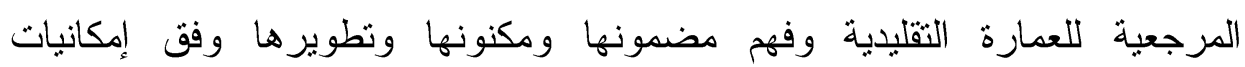

$$
\text { تكنولوجيا وروح العصر . }
$$




\section{منهج البحث:}

أعتمد هذا البحث على المنهج الوصفي التحليلي في وصف أزمة الهوية وما آلـــاليه

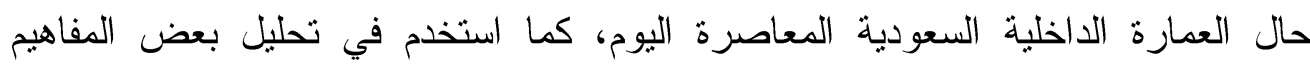
كالهوية و الخصوصية والأصالة و المعاصرة و التراث و الحداثة. في حين يستتد البحث اليضاً: على المنهج التحليلي التاريخي في رصد وتحديد أهم ملامح وسمات العمارة الداخلية

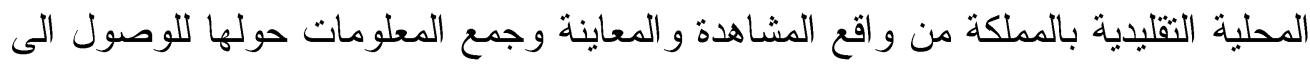

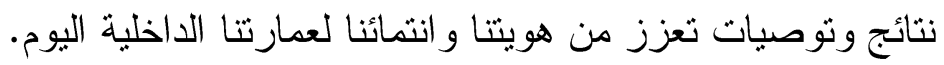

\section{التعريف بالهوية في العمارة الداخلية:}

أجتهذ مجموعة من الفلاسفة في تفسير مفهوم الهوية ففي كتاب التعريفات عند الجرجاني تعني الهوية (الحقيقة المطلقة)، ويرى البعض الأخر أنها (ما يعرف الثيء في في لهي

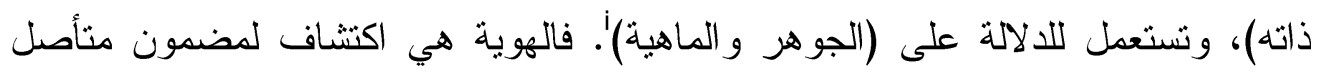
يحدد ماذا نكون فهي عملية بناء تعتمد على الظروف الاجتماعية و الثقافية السائدة ويربط وله

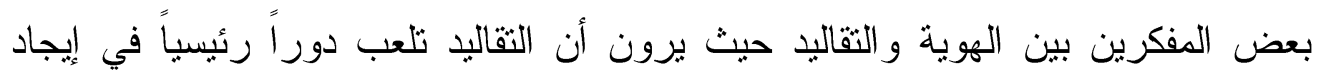

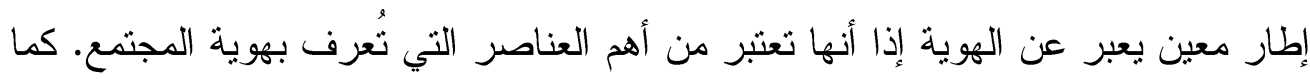

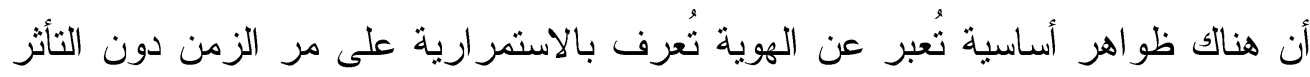

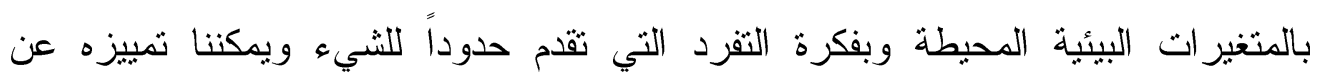

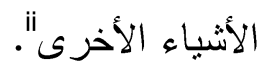

ويمكن تعريفها بأنها مجموعة الخصائص و المميزات التي تكشف عن طبيعة العلاقة

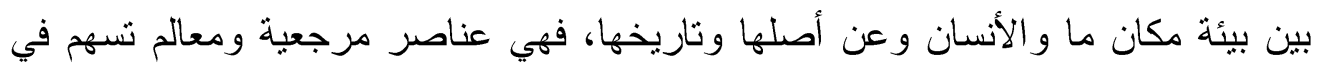

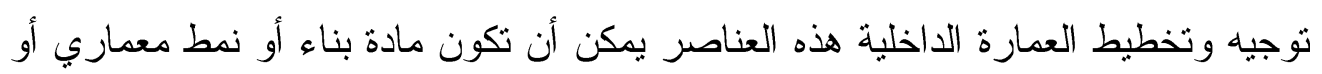
معلم أثري.

\section{الأصالة و المعاصرة في ظل ازمة الهوية:} الأصالة في العمارة الداخلية تعني الانتماء الى الأصل و الاعتزاز به به وكذلك الانتفاع

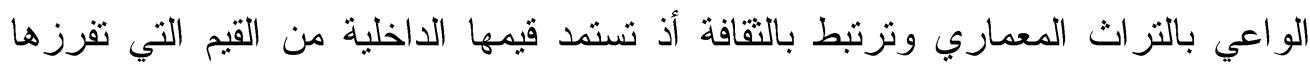

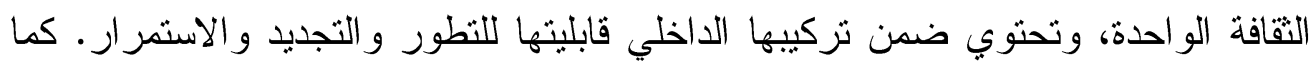




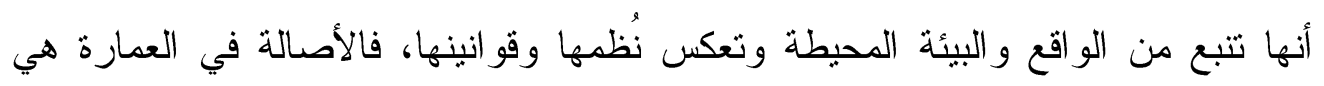

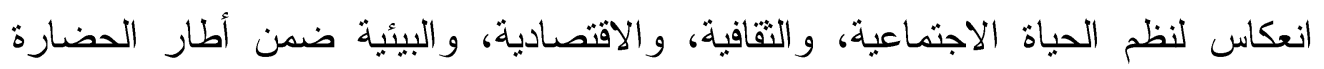

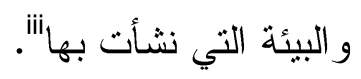

أما بالنسبة للمعاصرة فهي ترتبط من حيث مفهومها العام بالزمن، إذا أن معاصرة

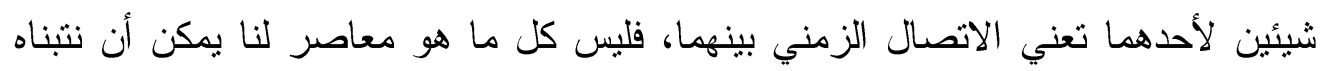

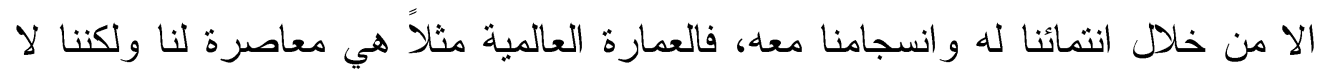

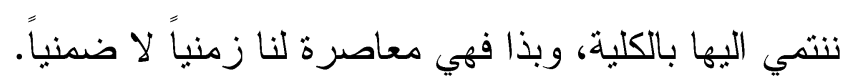
وتكمن اثكالية الهوية المعمارية التي نعاني منها اليوم في انقسام الادرالك الثنافي

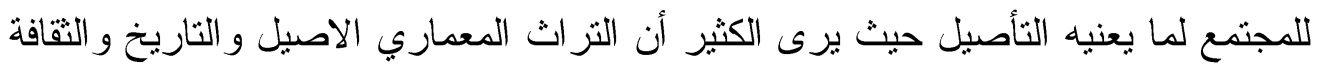

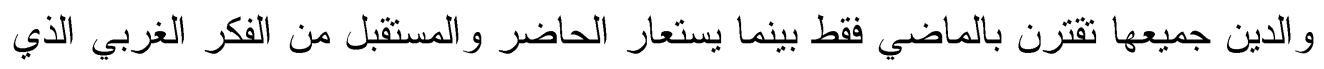

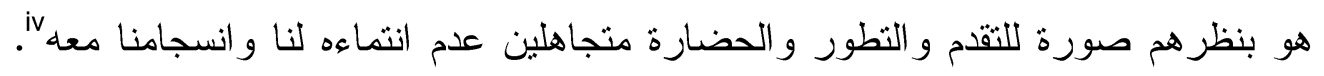

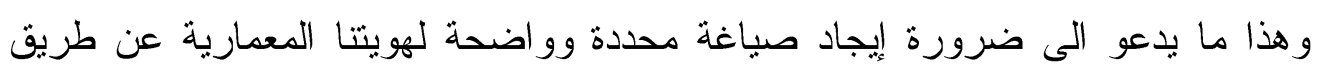

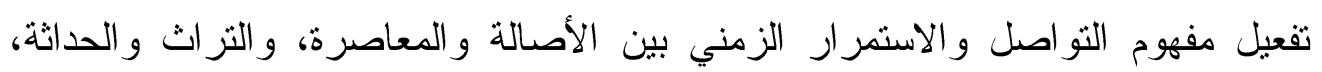

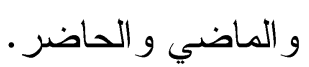

\section{إثكالية الهوية في العمارة الإخلية السعودية المعاصرة:}

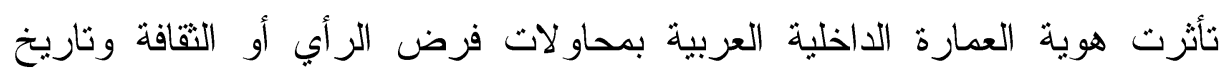

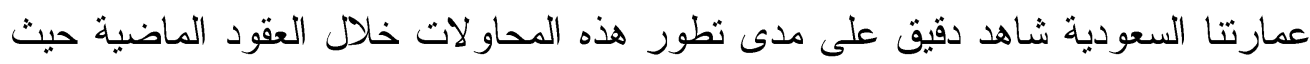

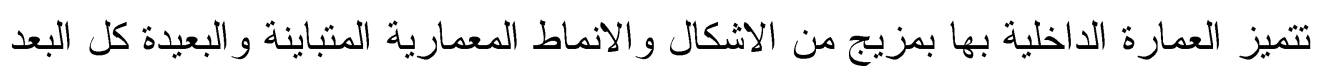

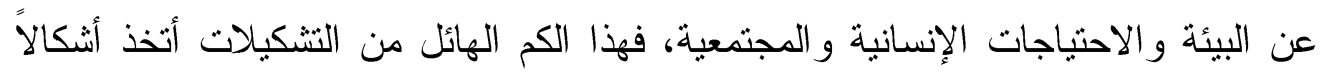
مختلفة حيث يظهر تأثر بعض المصمين السعوديين بالطرز الغربية ومحاولة النقل بدون

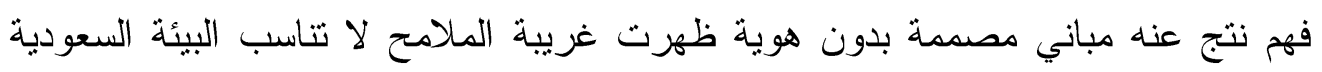

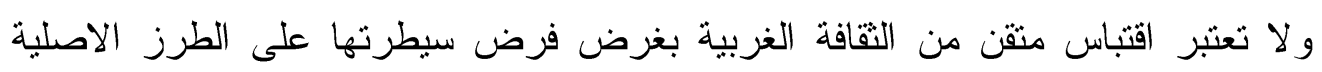

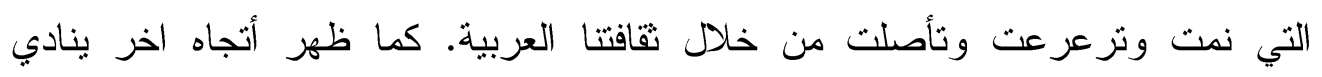

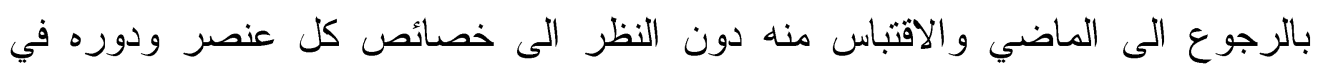

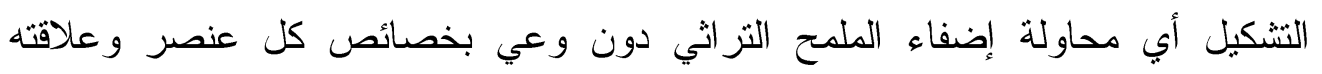

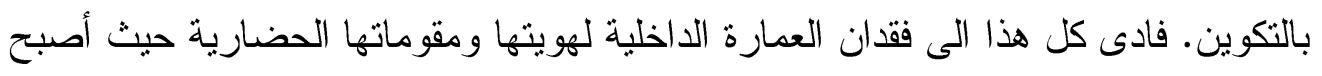


التغريب مبدأ يرمز الى التقدم و التطور ، و أصبحت العمارة المحلية المعاصرة مجرد عنصر مضاف لا تعبر عن جوهر الفكر المعماري لمجتمعنا الأصيل.

\section{العوامل المؤثرة على هوية العمارة الداخلية السعودية اليوم:}

هناك العديد من العو امل التي أثرت في هوية العمارة الداخلية السعودية اليوم ويمكن أجمالها

$$
\begin{aligned}
& \text { بالآتي: - باتي } \\
& \text { أ. قانئ قانين البناء. } \\
& \text { ب. التغير ات الاجتماعية. } \\
& \text { ج. تأثير النواحي الاقتصادية. }
\end{aligned}
$$

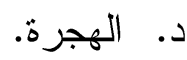

$$
\begin{aligned}
& \text { ه. تأثثير ثقافة المجتمع. } \\
& \text { و. التقدم العلمي و التكنولوجي. } \\
& \text { ز. العو امل السياسية. }
\end{aligned}
$$

\section{أسباب فقدان الهوية في العمارة الداخلية السعودية:}

تعتبر مشكلة غياب الهوية وافتقاد الخصوصية في العمارة الداخلية من أهم المواضيه اضيع الهوديه

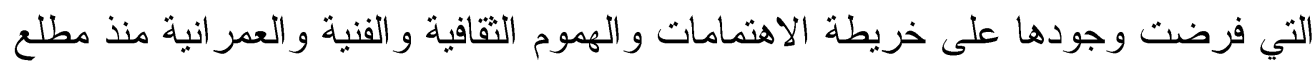
الستينات الى وقتتا هذا، ويمكن أجمال اهم أسباب فقدان الهوية في العمارة الداخلية السعودية المعاصرة اليوم كالاتي: 1. القفزة النوعية و التبدلات الاقتصادية التي حدثت للمجتمع السعودي بعد اكتشاف النفط

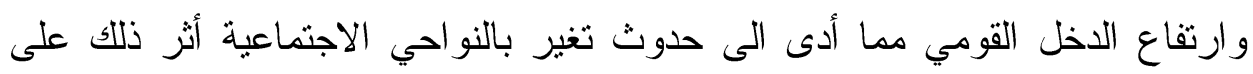

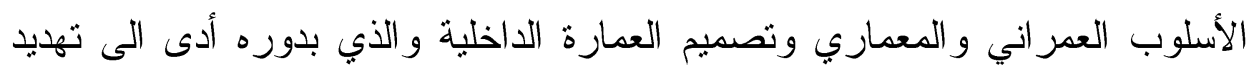
المباني العريقة و التقليدية بالمملكة ومن ثم اندثار ها و اختفائها تدريجياً.

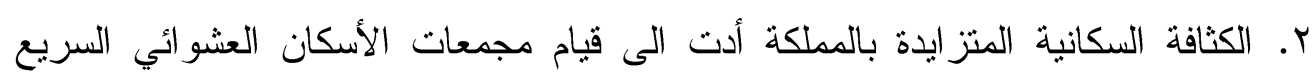
و الغير منظم مما تسبب بحدة أزمة السكن. r. سيادة الفكر الغربي و الذي انتقل الى بلادنا بالهيمنة و السيطرة الاقتصادية حيث ترك

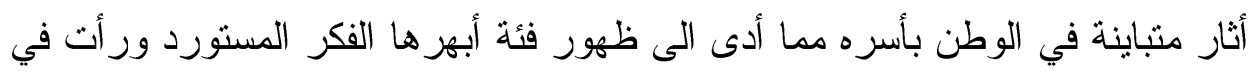


عمارة الغرب المثال المحنذى به لكل المنطلبات وذللك قاد الى النقل بلا وعي من العمارة الغربية وتقليد اتجاهاتها دون تفكير بخطورة ذللك في محو الثخصية والهوية العربية السعودية في العمارة الداخلية.

ع. ظهور جيل من المصممين و المعماريين يرفضون الماضي بكل صوره ويرفئهونه شعار

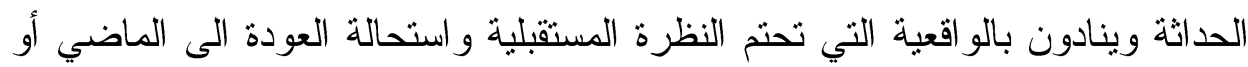
الحنين له، أو ينظر الى التزاث نظرة سطحية أو يستخدم مفرداته وينقلها بطريقة

$$
\text { خاطئة: }
$$

ه. الدمار الذي لحق بالتزراث التقليدي إضافة الى المخاطر الطبيعية و البشرية و الاهمال وسوء أعمال الثرميم و الصيانة ومحاولات الهدم المتسارع للمواقع ومعالم التزاث التقلبدي وتشويهه وطمس هويته.

\section{سلبيات العمارة الاخلية السعودية اليوم:}

أدت التبدلات الاقتصادية التي حدثت للمجتمع السعودي في العقد الثالث من القرن العشرين بعد اكتشاف النفط وارتفاع الدخل القومي الى حدوث تغير ات بجميع نو احي الحياة وخاصة المعمارية حيث بداء الزحف العمراني الحديث يجرف أمامه التزاث المعماري

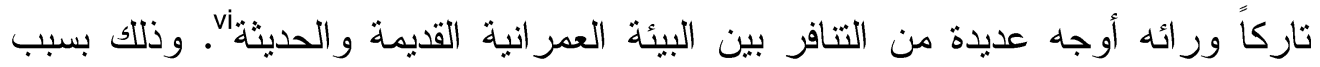
الاعتماد على شركات ومكاثب أجنبية في تخطيط وتصميم وتثيبيد المشاريع المعمارية

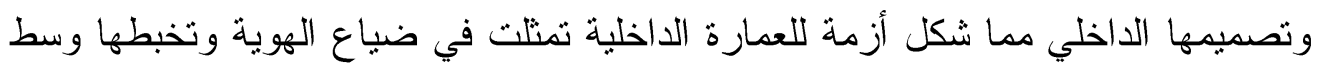
تيار ات مختلفة، فتحولت العمارة وتصميمها الداخلي من وحدة اللون و الطابع إلى تعددية المذاهب ومن فر اغات معمارية مفتوحة إلى الاخل تثميز بالتمحور إلى فر اغات مطلة على وهلى

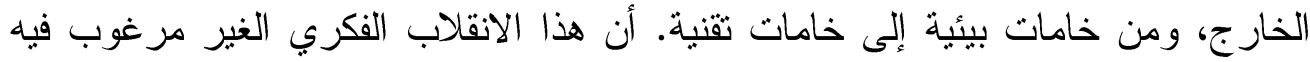
نقل المجتمع السعودي من عصر تقليدي إلى عصر منطور نمشياً مع المظاهر الحضارية للقرن العشرين بالدول المتقدمة'، لقد كان الخلل منذ بدايته يكمن في جهل المخطط الأجنبي بالبنية الاجتماعية للمجتمع السعودي ونظم العلاقات الإنسانية بين الفرد و الجماعة، بالإضافة بلانة إلى اعتماده على الوسائل التكنولوجية في المقام الأول في توفير بيئة اصطناعية وتجاهل

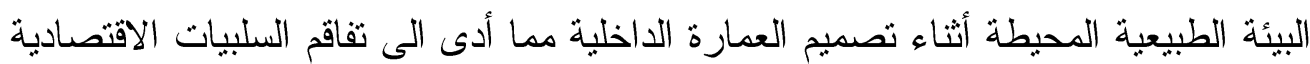
المتمثلة في الأسراف الثديد في استهلاك الطاقة. فالتصاميم التي وضعت أغفلت كل المقومات البيئية و الاجتماعية و الروحانية، فأزيل كل ما هو قديم بحجة عدم مسايرثه 
للحديث. كما تميزت المباني وتصميمها الداخلي بالرغبة في التباهي و التزف وحب التميز وبالمبالغة في الأشكال الهندسية المختلفة حيث خضعت للجمود المتمثل في استخدام المسقط الأفقي غير المنتظم الى جانب استخدام الأشكال الحرة التي تفي بالغرض الجمالي متجاهلة الغرض الوظيفي، هذا وقد اختلفت علاقات الكتلة المبنية و أهمية المباني ووظائفها، واختيار

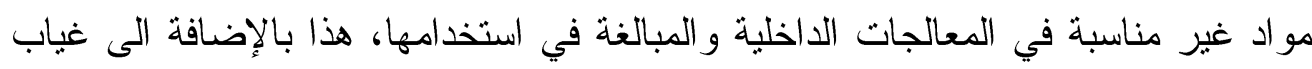
مبدأ الخصوصية حيث أصبحت المباني لا تحقق أقل المعايير الصالحة للسكن نتيجة لقو انين

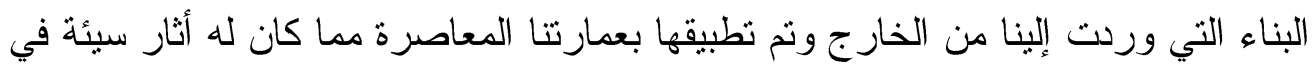
ظهور قصور شديد في عدم ملائمة التصاميم المعاصرة لاستيعاب احتياجات الأنسان

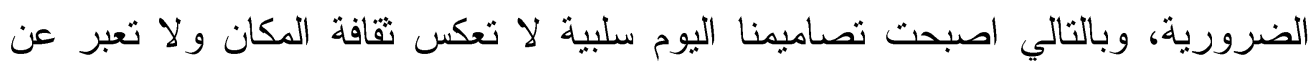

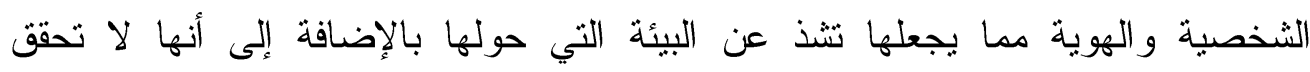
الغرض منها من الناحية الوظيفية و النفعية و الجمالية و التقافية و الاقتصادية.

\section{ملامح وسمات العمارة المحلية التقليدية بالمملكة العربية السعودية:}

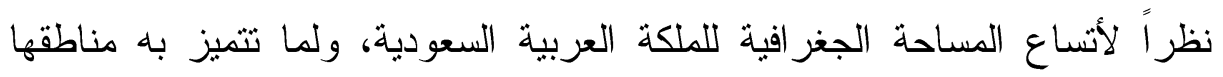
المختلفة من تتوع كبير في الخصائص المناخية و الطبوغر افية و البيئية واختلاف مو اد البناء

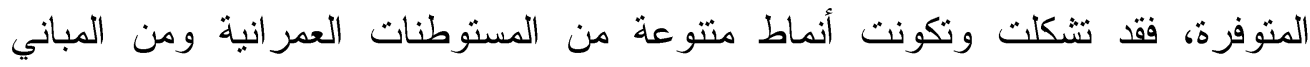
الثقليدية في كل منطقة جغر افية، حيث تثميز هذه الأنماط بكفاءتها وفعاليتها كحلول

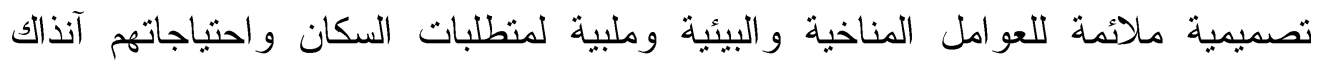
وبالرجوع الى هذه النماذج بالدر اسة و التحليل تتضح المعايير و الحلول المعمارية المستخدمة ولئه

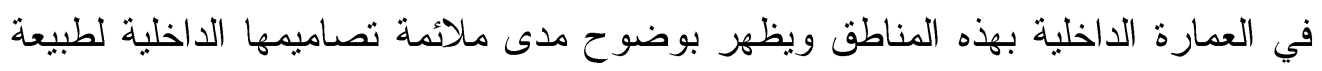
البيئة و المناخ، ويمكن حصر هذه الأنماط كالاتي: أ. نمط المنطقة الوسطى (الطراز النجدي):

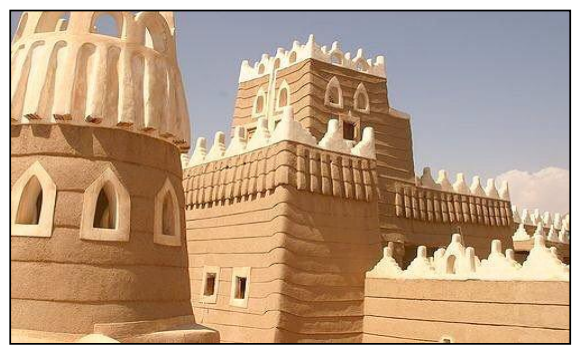

يمتذ هذا الطراز فيشمل المناطق الو اقعة في شمال المملكة وشمالها الغربي كالرياض و القصيم وحائل والجوف وتبولك حيث تسود البيئة الصحر اوية مما جعلها نسير على نهج ونه المنطقة الوسطى في البناء بالطين. هناك علاقة 


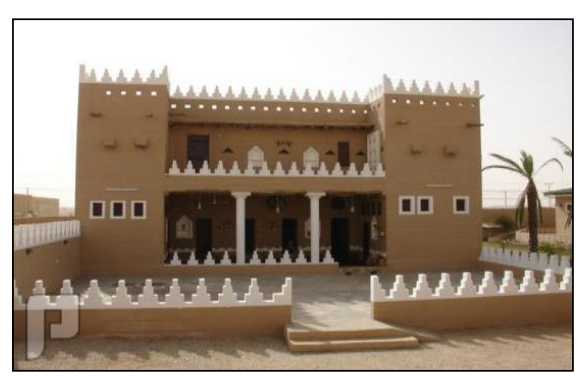

(1) شئل (1)

نمط المباني التقليدية في المنطقة الوسطى (1)

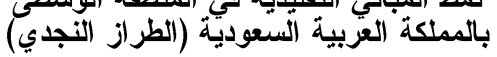

بين نمط العمر ان و البيئة السائدة ، فالبيئة تفرض معال ظروفاً معينة ترغم سكانها على التكيف معها،

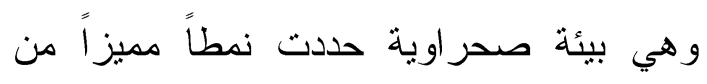
العمران التقليدي. كما أن للظروف البشرية، هئه و الدينية، و الاجتماعية، و الاقتصادية دوراً مهماً في تشكيل البيئة العمر انية بالمنطقة؛ فالمسجد ولهد

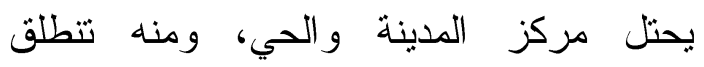

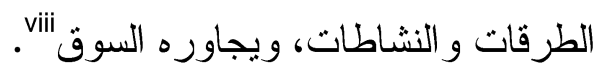

يتصف نمط النسيج العمراني بضيق الطرقات وبتراص المباني بارتفاعات متقاربة لتقوم بدور الحماية لبعضها من شدة الرياح و الحرارة ووهج الثمس كردة فعل للمؤثرات المناخية، و الثوارع بوجه عام ضيقة ومتعرجة بحيث ثوفر أكبر قسط من الظلال لحماية

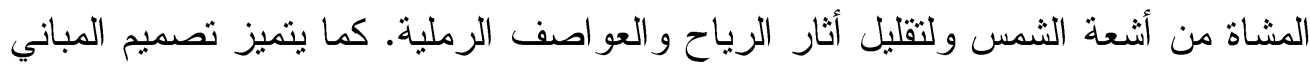
بالبساطه و التجانس في مفرداته العمر انية فتتساوى المنازل وتتماتل في كل مظاهر ها تقريبا؛ فلا نطاول و لا تفاخر في البنبان؛ مما أدى إلى تقارب المجتمع ونز ابطه وذلك بشعر الأنسان بالانتماء و الطمأنينة.

المنزل الثقليدي فيبدو وكأند قلعة مغلقة تتلاءم مع العادات و التقاليد وخصوصية ساكنيه و النشاط الزر اعي هو الغالب على حباة السكان لذلك اتخذت معظم القرى التقليدية

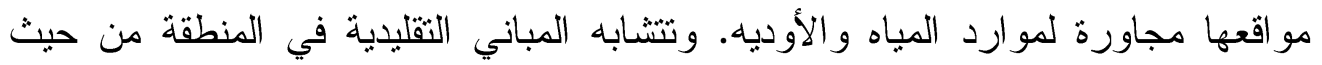
شكلها ومظهرها الخارجي فتتميز ببساطة الزخارف و التقاصيل وخاصة في الو اجهات الخارجية، ويأخذ التصميم الأساسي لأي منزل الثكل المسنطيل ،ومعظمها تنتكون من لناطيل

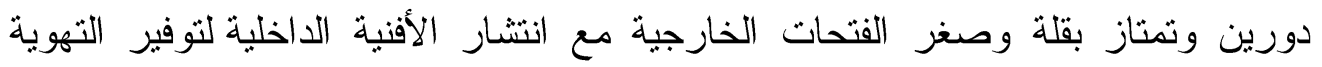
و الإضاءة الطبيعية. ينقسم المنزل بصفة رئيسة إلى قسمين أحدهما للرجال و الآخر خاص

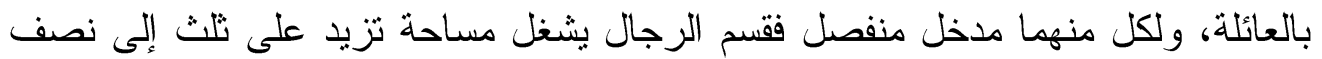
مساحة المنزل يحتوي على مدخل ومجلس يستخدم لاستقبال الضيوف وهذا القسم يتصل

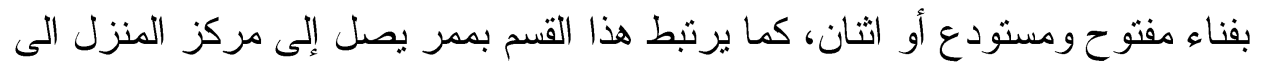


البهو الكبير الذي يربط بين أقسام المنزل المختلفة، وتحبط بالبهو الغرف الرئيسة

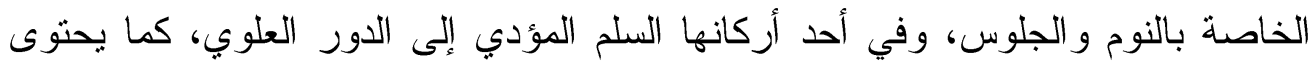
المنزل على حوش يضم عدة مر افق كالمطبخ ومكان الوضوء وحظائر تربية الحيو انات ولهات و الطيور • ويرتبط الحوش بمدخل النساء المصمم بخصوصية جيدة. ويحتوب الدور الأول

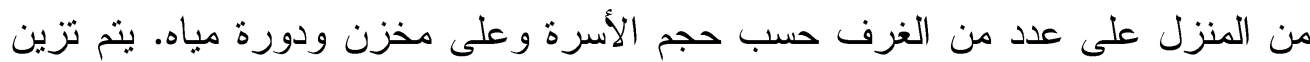

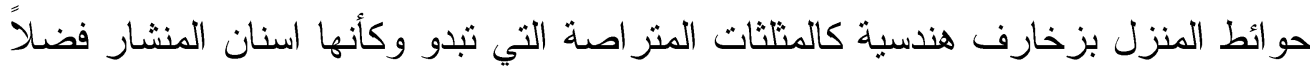
عن الشرفات المتدرجة.
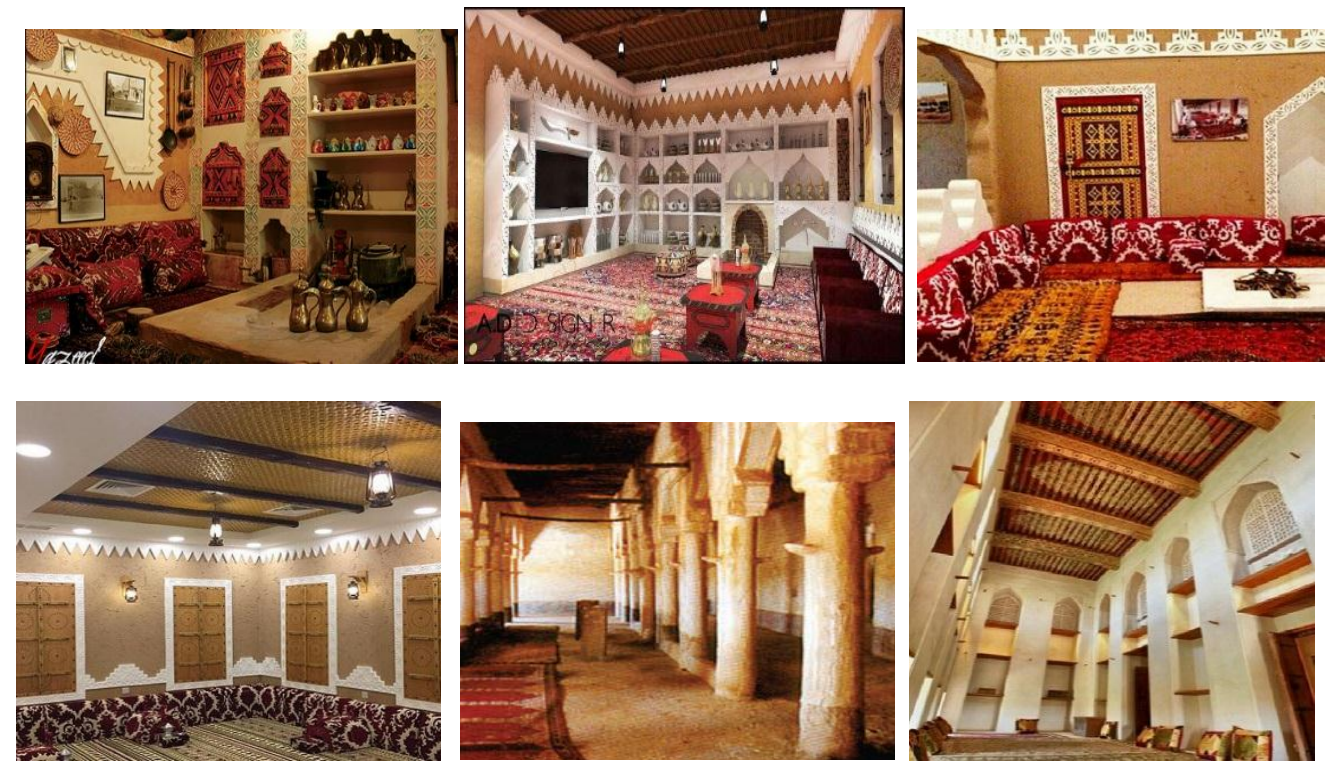

شكل (r)

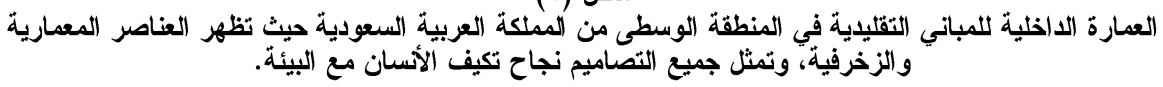

\section{ب. نمط المنطقة الغربية (الطراز الحجازي):}

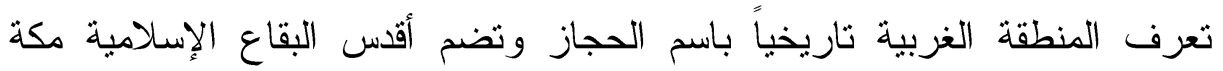
المكرمة و المدينة المنورة؛ كما تضم بقطاعاتها: الثمالية و الوسطى و الجنوبية مدناً أخرى

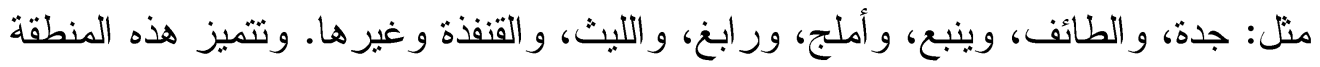

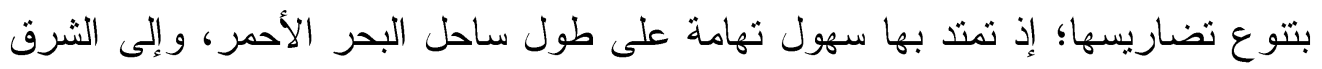

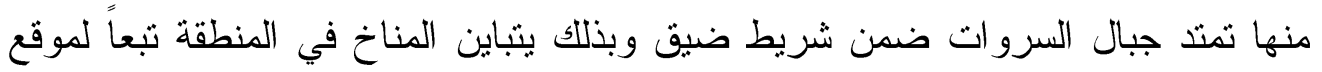


مدنها؛ ويتركز النشاط الاقتصادي في المنطقة في ثلاثة أنشطة رئيسة هي: خدمات الحج

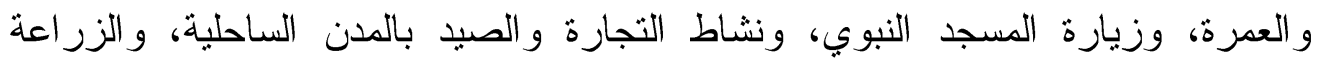

$$
\text { و الرعي في السهول الداخلية. }
$$

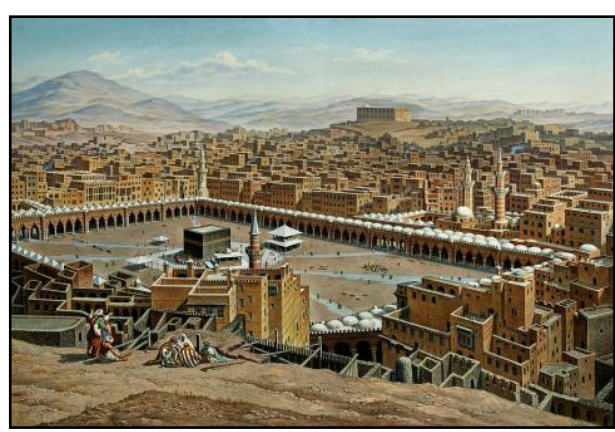

شكل (r)

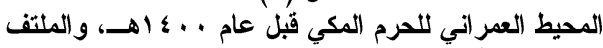

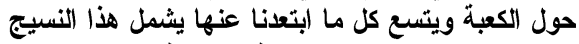
استخامات سكنية وتجارية.
وقد أثر وجود الحرمين الشريفين بمكة

و المدينة في تكوين نسيج متر ابط يشكل كلاً منهما نو اة للمدينة ومركز الها ونسبة البناء في المناطق المحيطة بكل حرم تفوق نسبة الفراغ، فيشكل البناء كتلة مستمرة تصل إلى ألى لهالي الجبال رغم صعوبتها مما أعطى التكوين

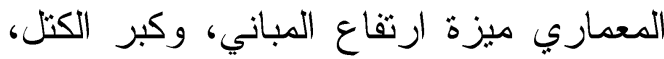
أما بالنسبة للمدن الساحلية حيث الحرارة المرتفعة فقد اتخذ نسيجها شريطاً على الساحل

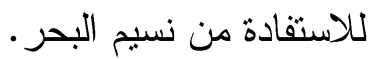

تمتاز المباني في المنطقة الغربية بارتفاعها وتعدد أدوارها وبكثرة و اتساع الفتحات الخارجية المغطاة بالرو اشين و المشربيات، حيث تأثر تشكيل المباني بعاملين أساسيين هما

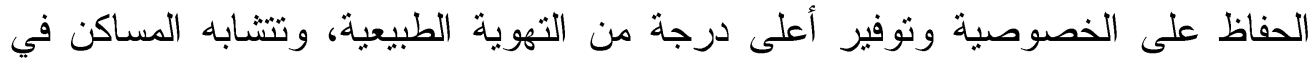
التصميم الداخلي وفي توزيع الغرف واستخداماتها، ويكون الاختلاف إن وجد في اتساع

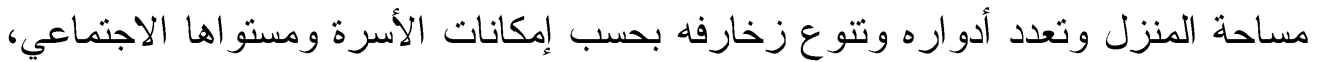
تتو افق المساكن في توزيع الوظائف لكل طابق فيتسم المسقط الأفقي للادور الأرضي بوجود ودود الدهليز أو الحوش الداخلي و الدرج ومقعد مخصص للجلوس و استقبال الضيوف و النوم ودورة للمياه، و هذه الغرف قد تزيد أو تتقص، وذلك بحسب قدرة الأسرة المادية، وقد يكون للبيث أكثر من مدخل: اثثان على الغالب، أحدهما للرجال، و الآخر للنساء و أفر اد العائلة.

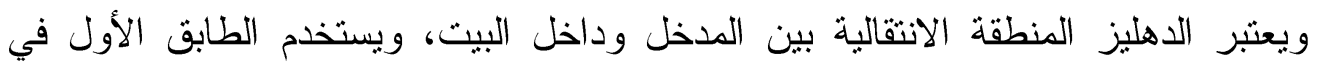
بعض الأحيان لاستقبال الضيوف من الرجال، أما الطوابق العليا فهي خاصة للأسرة وفيها المجلس وهو أكبر غرف البيت و أحسنها فرشاً يستخدم لاستقبال الزوار من الإن النساء، ويقع في

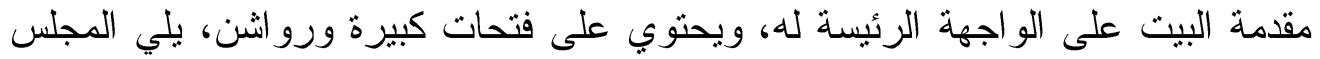
غرفة صغيرة ملاصقة له تسمى الصفة تستخدم كغرفة معيشة، كما تقع في مؤخرة البيت 
غرفة منوسطة الحجم تسمى المؤخر تستخدم كغرفة لجلوس نساء العائلة، ويلي ذلك غرفة صغيرة لإعداد الطعام تسمى بالمركب بجانبها دورة المياه. تميزت البيوت النقليدية بهذه المنطقة بتنوع وكثرة العناصر الزخرفية على حواف الأسطح وقمم الرواثين و الجدران و الأسقف، وتكون نوعبة الزخارف هندسية ونباتية

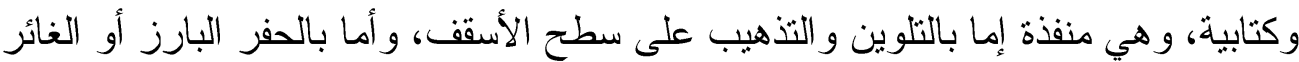
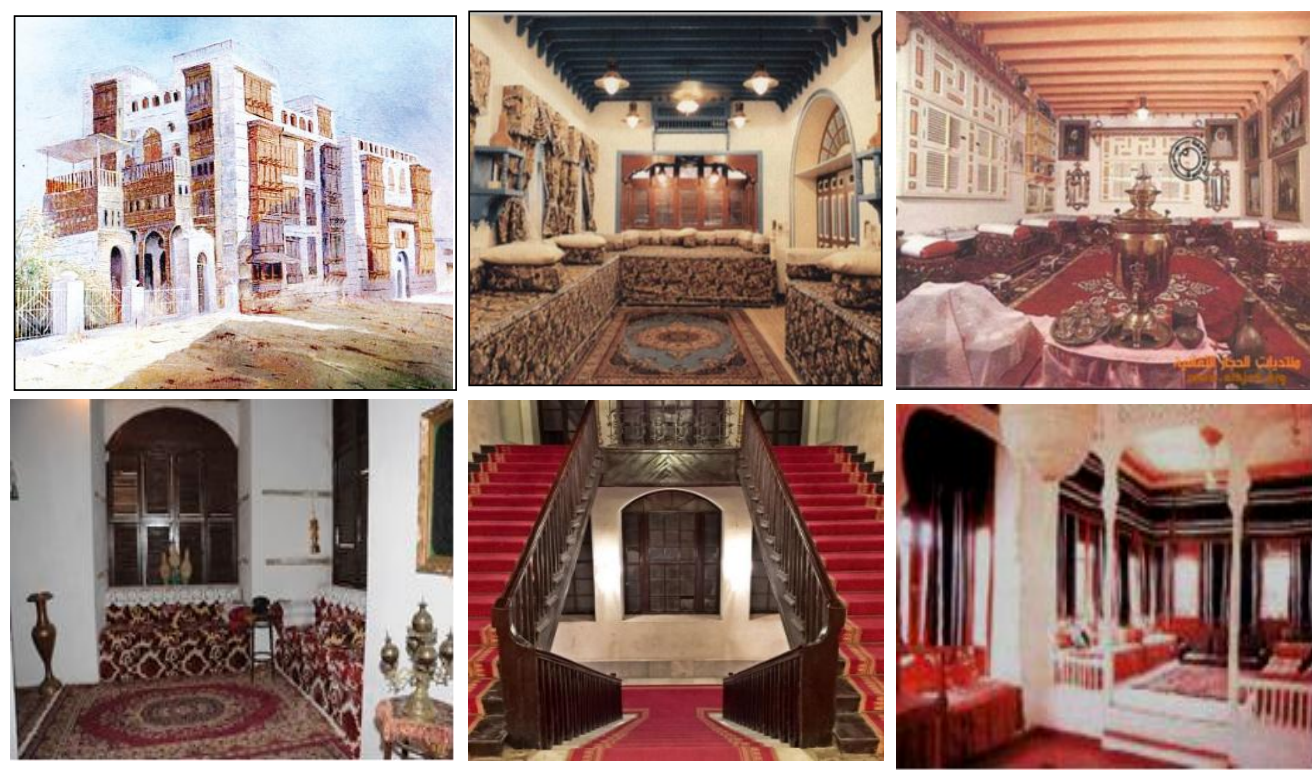

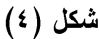

التصميم الااخلي للمباني التقليدية بالمنطقة الغربية من المملكة حيث تظهر أهم العناصر والمظاهر التصميمية والمعمارية التي تميزت بها المباني أن ذاكل

في أفاريز الجص والأشغال الخشبية، أو بالتفريغ المتمثل في برامق وعراميس الخرط في الرواشين و المشربيات، تكون الزخارف الهندسية على شكل اشعاعات ودو ائر

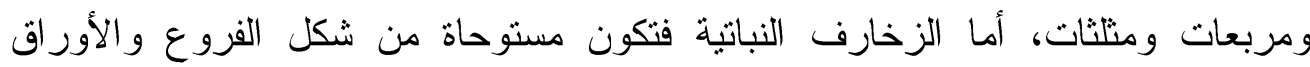

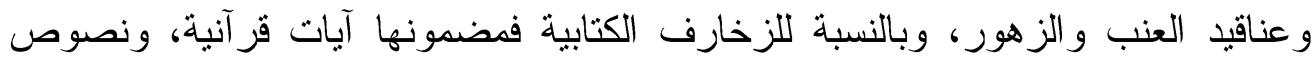

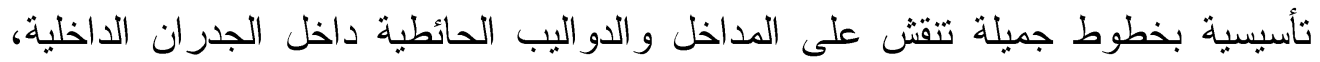
و على حواف الوزرات وأطر الأسقف. شيدت مباني هذه المنطقة من خامات المناطق

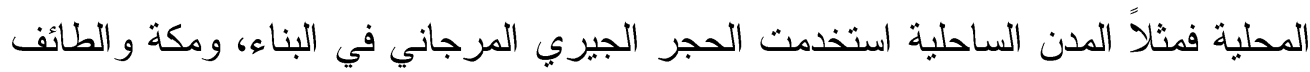

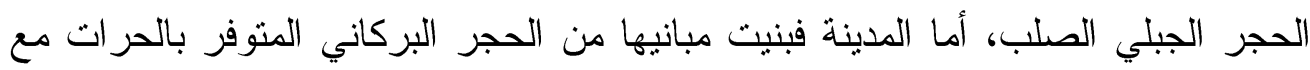


الطوب اللبن المنوفر في طمي أوديتها، واستعملت الأخشاب المحلية المتوافرة في البيئة كجذوع النخيل وجريده، وخشب الأثل والعرعر، و ايضاً بعض الأخشاب المستوردة عن فئن طريق البحر الحمر كخشب الساج الهندي وغيرهذاء.
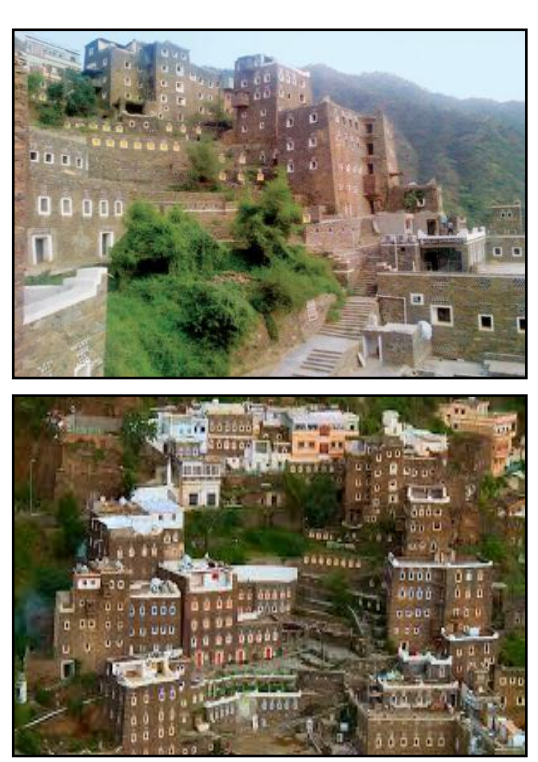

شكل (•)

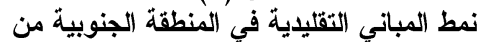

المملكة العربية السعودية (طراز العراة)

ج. مط المنطقة الجنوبية (طراز السراة): المنطقة الجنوبية تثمثل في المساحة التي

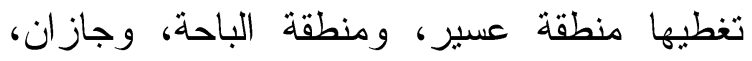
ونجر ان، وتتكون من مستوطنات وتجمعات سكانية

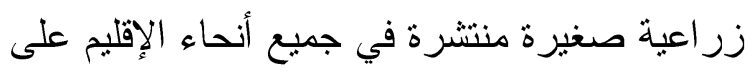
قمم وسفوح الجبال وفي تهامة الساحل، وتثميز بأنماط تصميمه متغايرة تبعاً لكل منطقة حسب وفي

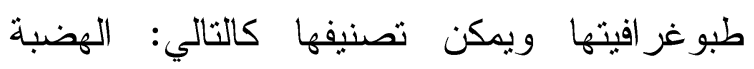
نجران، ومنطقة السراة المرتفعات أبها، ومنطقة الإصدار جبال فيفا، ومنطقة تهامة جازان. ولقد أثثت العوامل البيئية والاجتماعية والأمنية وكذلك هنية

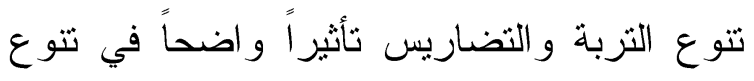

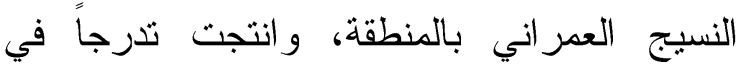
الأنماط التصميمية، سو اء في تخطيط المباني أو في بلي تصميم عمارتها الداخلية.

تشتابه خصائص فكرة التصميم في نجران (مباني الهضبة) مع مباني منطقة

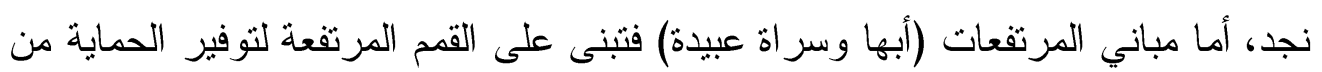
الأعداء ولتجنب السيول الجارفة على حواف الوديان، ويتم تشييدها من الخرسانة المسلحة

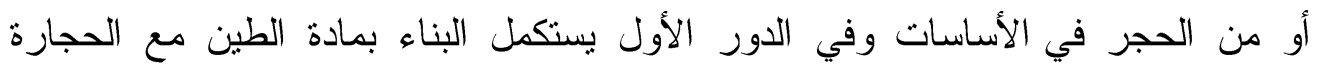
المسطحة فتبنى الحوائط من الطين المخلوط بشكل جيد بالتبن والماء على شكل مداميك لألى

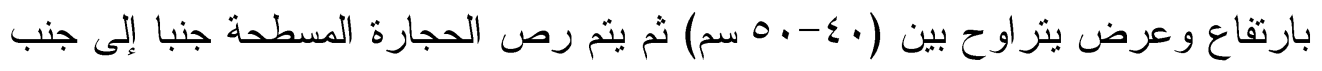

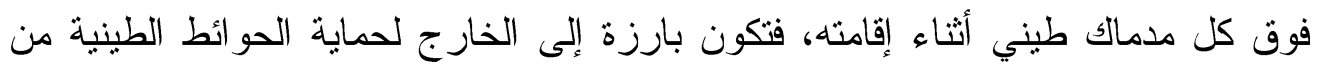
الأمطار الغزيرة، ويلاحظ أن المباني تضيق كلما ارتفعت الجدران بحيث يظهر المبني 
كالهرم الناقص، ولهذا الشكل ميزة بالإضافة إلى جماله وهو أنه يجعل المبنى أكثر ثباتاً،

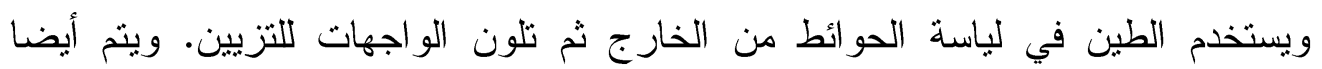
زخرفة المباني من الداخل حول حواف الأبواب، و النوافذ، والأسقف، وكذللك الأجزاء

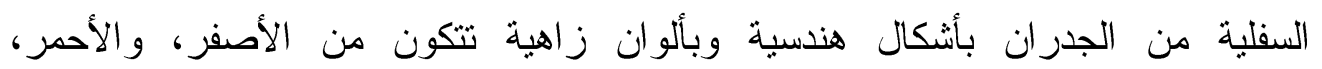

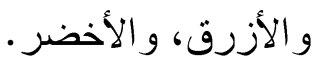
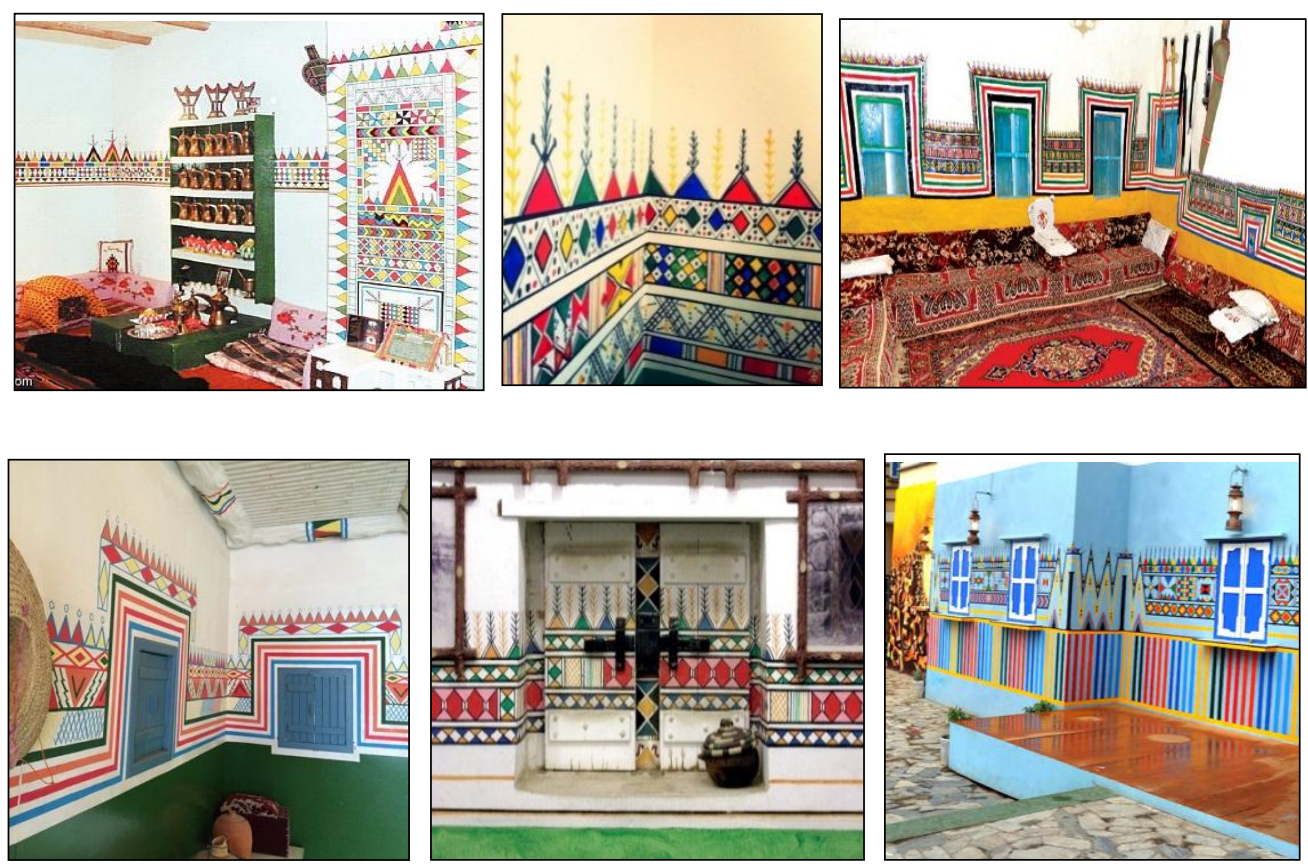

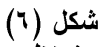

التصميم الاخلي للمباني التقليدية بمنطقة عسير حيث نظهر مزينة بخطوط وزخارف هندسية ملونة ومتنوعة. 


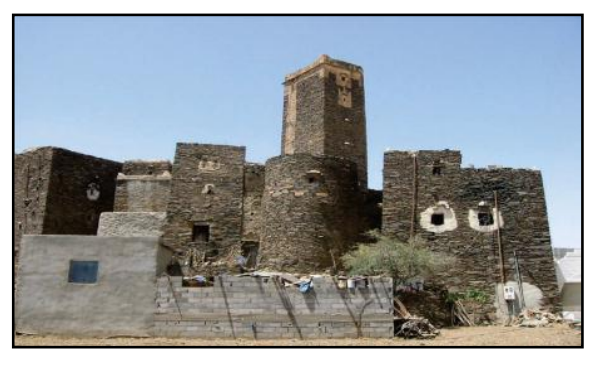

شكل (ᄉ)

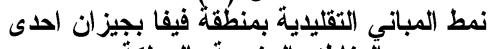
ألمناطق الجنوبية بالمثلكة.

وبالنسبة لمباني منطقة فيفا: فتشيد على

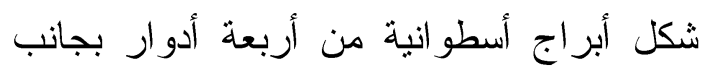

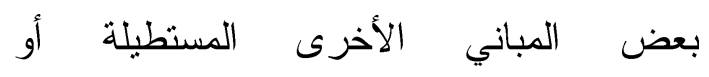
المربعة. حيث إن الشكل الأسطواني للمبني يعتبر شكلا دفاعياً مناسبا للحماية من الغار ات الت الترون

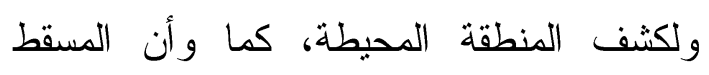
الدائري يقلل من الحاجة إلى استخدام الأخشاب الطويلة في التشقيف و التي يصعب توفرها في المنطقة. ولمقاومة تأثير حبات البرد والأمطار الغزيرة، ويتم بناء هذا النوع من المباني من الحجارة الجبلية غير المنتظمة، حيث يتم رصها على بعضها بدون استخدام المونة ونملأ الفر اغات المتبقية

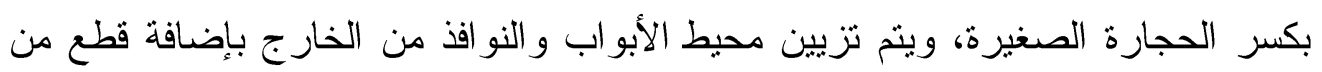
أحجار المرو البيضاء اللامعة كتكوينات هندسية بين أحجار البناء القاتمة اللون. مباني تهامة: تصمم على شكل عشش دائرية ذات سقف مخروطي الثكل يوحي بتأثير العمارة الإفريقية، وتنشأ العشة من جذوع وانئ وأغصان الأشجار و الحشائش الجافة و الحبال المفتولة وتغطى من الداخل بطبقة رقيقة من لياسة الطين و الجص. إن استخدام هذه ولهن المو اد في بناء فراغ العشة المخروطي الشكل يساعد على صعود الهواء الحار ودخان الموقد إلى قمة المخروط وتسريبه إلى الخارج من خلال الأعو اد و الحشائش وطبقة الطين الرقيقة، مما يسمح بتتفس العشة وتحرك الهو اء داخلها بشكل مستمر ، وبهذه الطريقة توفر التهر

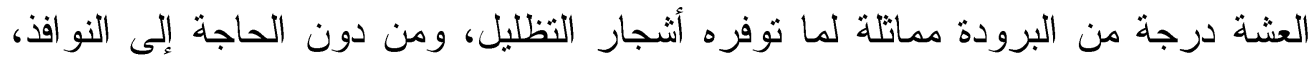

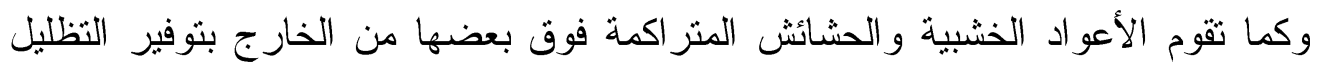

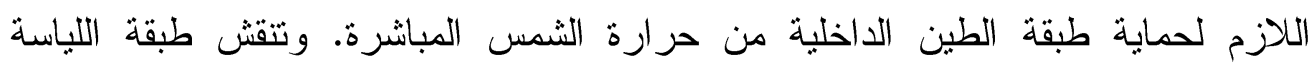

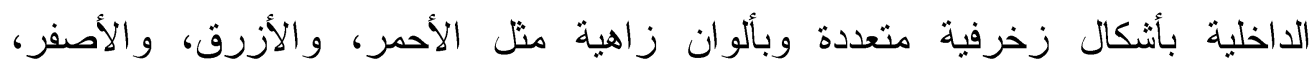

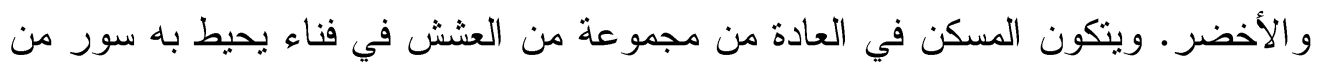

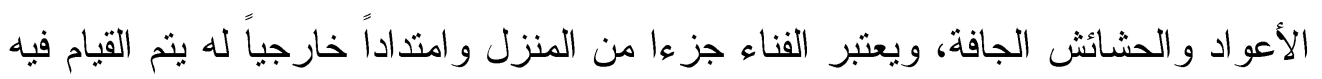
بالعديد من الأعمال المنزلية. 

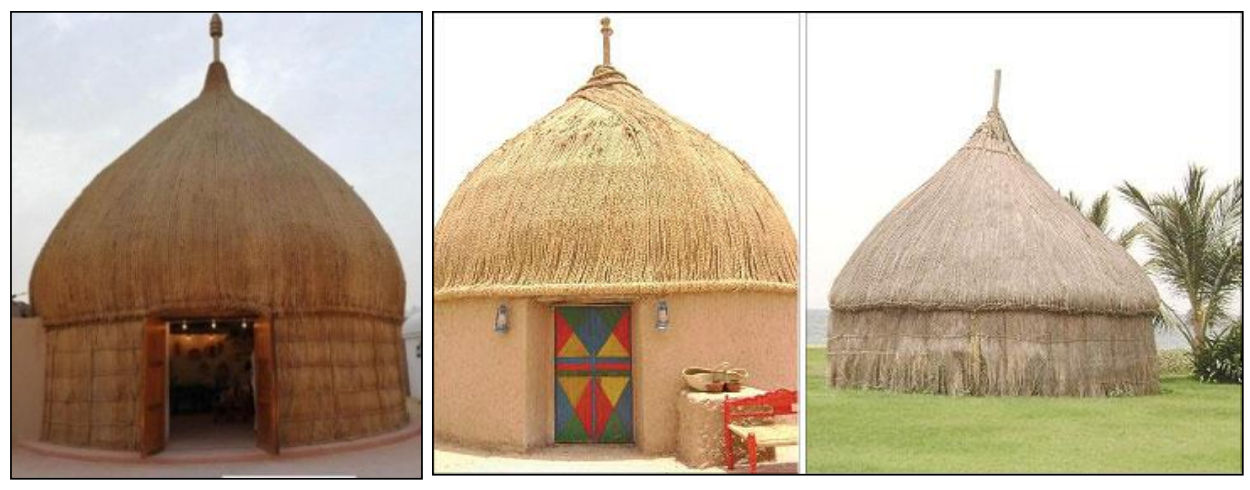

شكل (9) (9)

نمط المباني التقليدية النباتية بتهامة عسير إحدى المناطق الجنوبية بالمملكة (عشش دائرية ذات سقف مخروطي يوحي بتأثير (العمارة الأفريقية).

\section{د. نمط المنطقة الشرقية (طراز الخليج العربي):}

تتكون المنطقة الثرقية بالمملكة من مستوطنات ساحلية تعتمد على صبد الأسماك

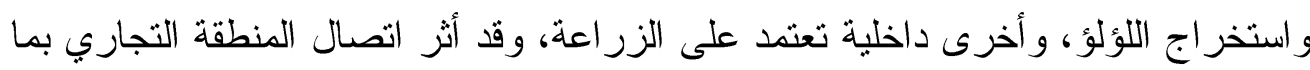

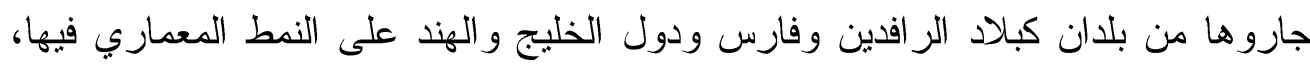

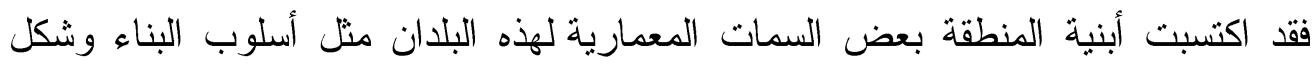

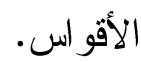
يتأثر النسيج العمر اني بعامل المناخ الحار الرطب فتظهر المباني منالاصقة مما يقلل الجدران التي تتعرض للشمس. و وتشيد المباني في المستوطنات الساحلية من الطين و الأحجار الرسوبية وجذوع النخيل وجريده ومن أخشاب الجندل حول فناء داخلي، وتبرز على الواجهات الخارجية التكوينات الإنشائية بشكل هندسي متعامد تضم بينها فتحات للمعالجة بشكل يحفظ الخصوصية ويوفر أقصى درجة من التهوية الطبيعة، وشاع استخدام

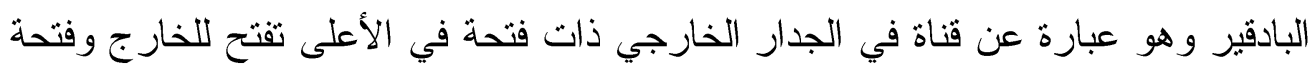
بالأسفل تفتح بالسطح أو داخل الغرف، ووظيفته نوجيه الهو اء إلى السطح وجلب الته التبار التهات

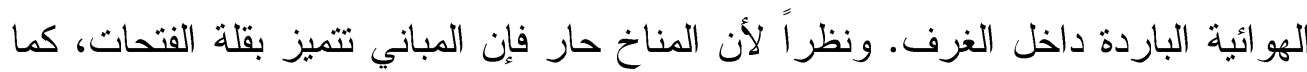

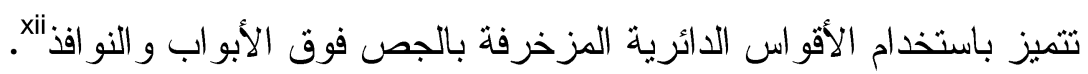



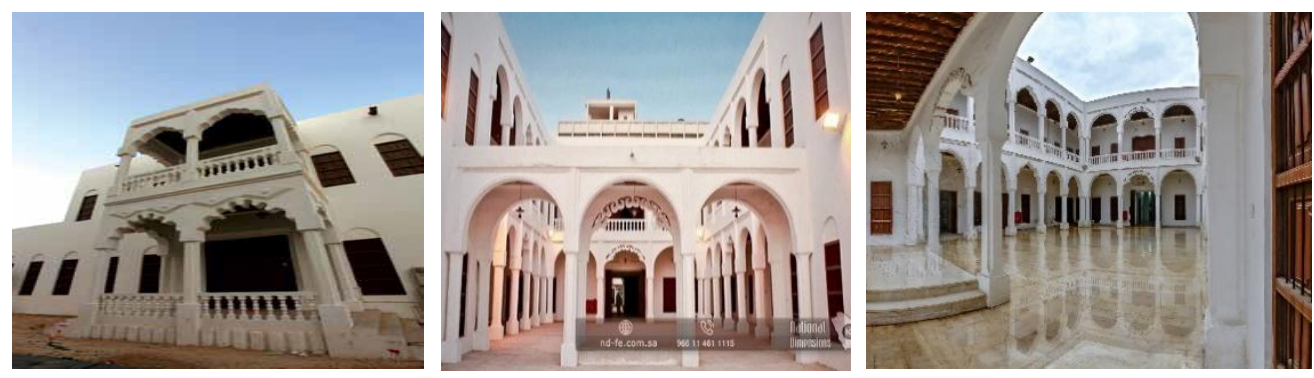

\section{شكل (• (1) المدرسة الأميرية.}

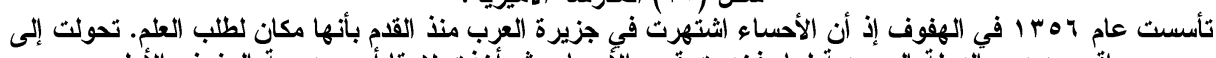

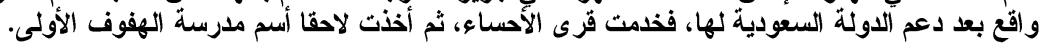

يتميز تصميم المباني السكنية بتكوينه الذي يتألف من ثلاثة أجزاء رئيسية: الأول مخصص للضيوف ويظم المجلس العام ومكان للغسيل يبنى هذا الجزء من خامات جيدة ويكون غنياً بالزخارف، أما القسم الثاني فيخصص للعائلة ويظم غرف النوم و الحمامات و المطبخ ومستودع الأرزاق وفناء داخلي خاص بالعائلة، أما القسم الثالث عبارة عن فناء مفتوح مخصص للبهائم منصل بالبيت عن طريق باب. كانت الحو ائط تستعمل كمرشحات للهو اء البارد و موجهة لتيار اته بالإضافة الى وظيفتي الوقاية و العزل، ويصمم مدخل المسكن من النوع المنكسر ذو ممرات وردهات مثتابعة موصلة الى الفناء الداخلي أو المجلس ويركز الاهتمام على كتلنه المعمارية وبابه الخشبي من حيث الزخارف و الألوان و الرموز . وروعي في تصميم النو افذ مسألة الخصوصية من حيث اتساعها ومواضعها وتغطيتها بالمشربيات و الزجاج المعشق بالجص.

وتثميز مباني المنطقة بتتوع عناصر ها الزخرفية سواء في الخارج أو الداخل حيث

تزين بإطار ات زخرفية من وحدات نباتية و هندسية محفورة وبأفاريز جصية ذات زخارف تجريدية. وتستخدم مو اد نهو ملساء ذات ألوان فاتحة لتحقيق الانعكاس المباشر لأشعة الشمس، وروعي أحاطه المبنى بمسطحاث خضر اء كثيفة للتقليل من حدة أشعة الشمس الساقطة. 

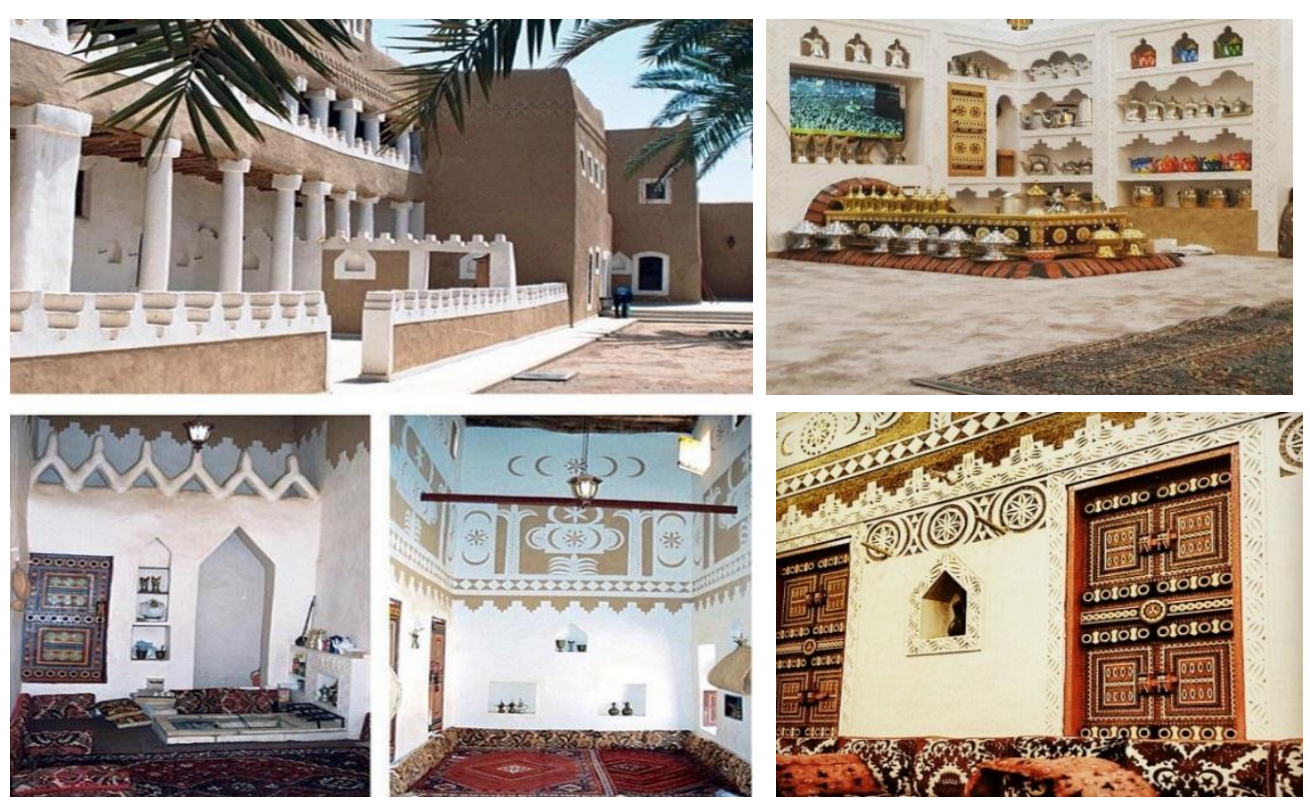

شكل (11)

التصميم الاخلي للفراغات بالمباني التقليدية للمنطقة الثرقية من المملكة( طراز الظليج العربي) حيث تظهر مزينة بزخارف متنوعة لعنة

ومن خلال هذه النقطة البحثية يمكن استتناج أهم مبادئ ومميزات العمارة الداخلية التقليدية بالمملكة و المتمثلة في الآتي:

$$
\begin{aligned}
& \text { - المو اعمة مع الظروف المناخية. } \\
& \text { - التوجيه الى الداخل. } \\
& \text { - المرونة وقابلية التكيف و الامتداد. } \\
& \text { - التجريدية و الرمز . }
\end{aligned}
$$

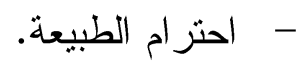

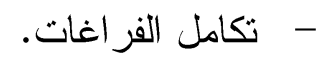

تأصيل الهوية في العمارة الاخلية السعودية المعاصرة:

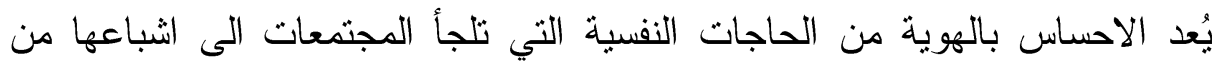

خلال التعبير عن ذاتها بتجسيد عناصر ورموز مُسنقاه من ثقافتها وذاكراتها في بيئتها العمر انية وفي طريقة عيشها، وبذلك تؤمن وتصون وحدتها و استمر اريتها حيث ان الوظيفة

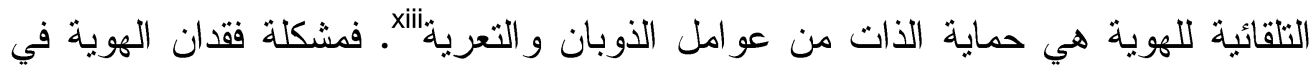
العمارة الداخلية هي مشكلة تحتاج من المسؤولين لإعادة النظر وتكوين أتجاه واضح بايجاد

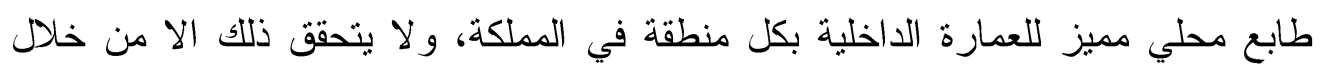


تشريعات وقو انين البناء و التصميم وتو اجد فريق عمل، وأن يكون للتزاث المحلي مكاناً

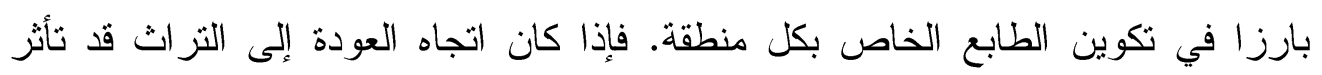
بصورة غير مباشرة ببعض الأسباب الثي أثرت به مثل قلة عدد المعماريين السعوديين

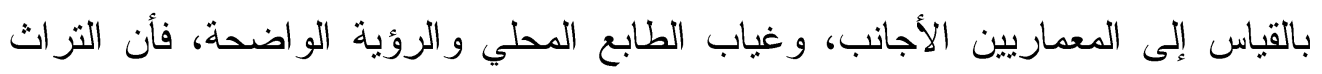

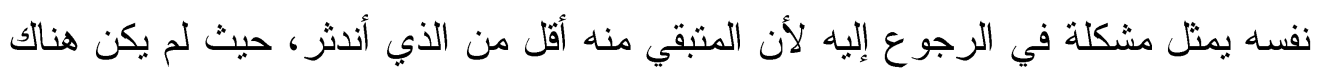

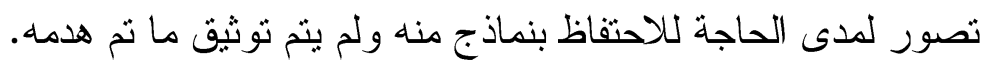

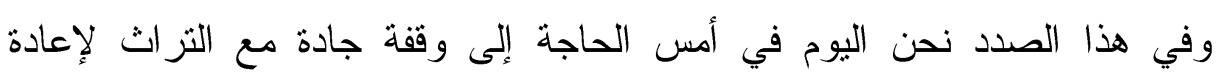
صياغته وفق ما تتطلبه ضروريات العصر وما تقتضيه ظروف المرحلة الراهنة

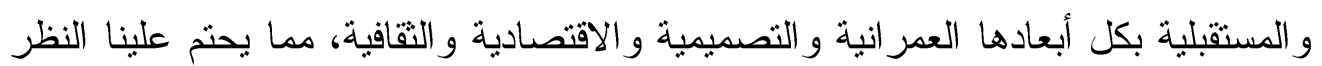

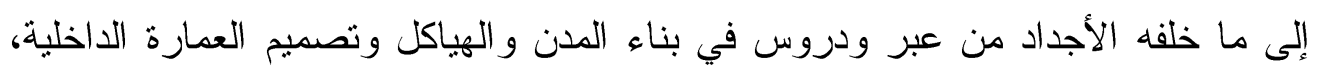

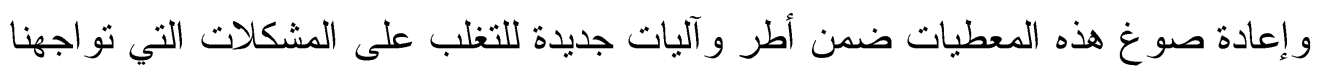
اليوم في تصميم عمارتتا الداخلية.

ومن هنا يمكن ايجاز أهم طرق الحفاظ على الثزاث التقلبدي المعماري بالمملكة في الاتي:

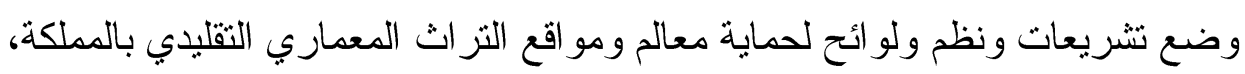
و أنباع العديد من سياسات التخطيط للحفاظ عليها وحمايتها مثل سياسة أعادة البناء و التزميم، و التجديد، و إعادة التأهيل، و إعادة الاستخدام و التوظيف.

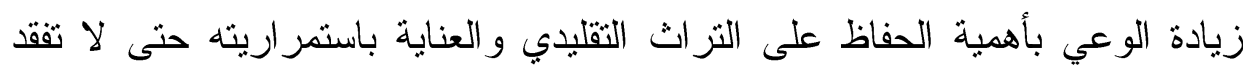

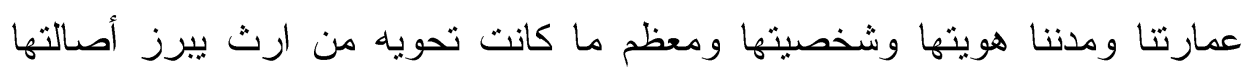

وعر اقتها.

أن يتدارك المسئولين في الأمانات و البلديات أهمية اتخاذ الإجراءات اللازمة لحماية

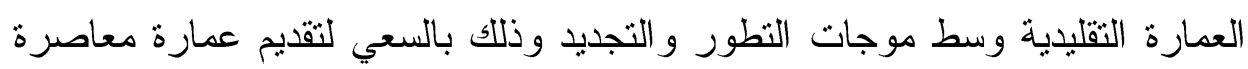
ومنتمية في حدود الإمكانات ومعطيات العصر .

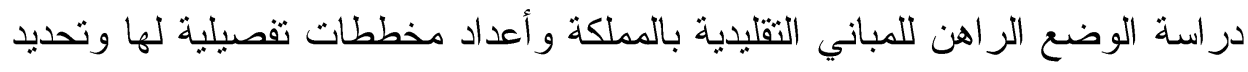
حالتها وعناصر ها التصميمية حتى بمكن فهم خصائصها مما بسهل عملية النقل منها. ولقد حدد البعض أساليب استلهام أو أحياء التزاث التقليدي بعدة طرق يمكن للمصمم

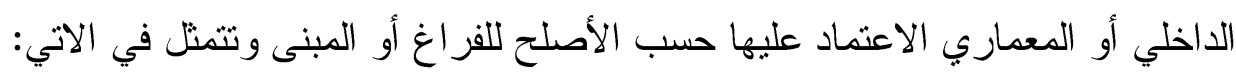




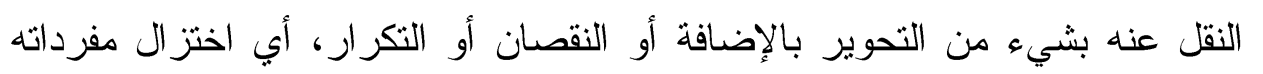

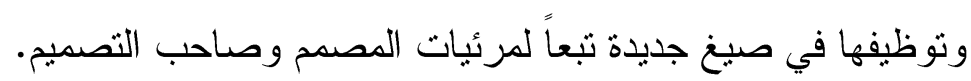
القياس عليه وتطويره.

أخذ مسبباته في الاعنبار ومحاولة إعادة استخدامه بفكر تصميمي جديد أو مبتكر لون وتتمثل أهم أساليب تأصيل التراث وتوظيفه في العمارة الداخلية السعودية المعاصرة في الاتي:

أ- إرساء الفكر التز اثي للعمارة الداخلية السعودية و إنشاء جسر تو اصل كبير يربط الطابع العام للعمارة التقليدية بالعمارة الحديثة من خلال تفهم امكانيات العصر الذي نعيشه

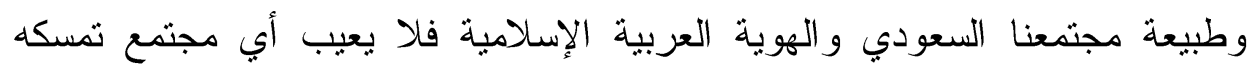
بعاداته وتقاليده وملامح شخصيته وتر اثه بل ما يعيب هو التشابه بالآخرين بدون وعي. ب- التأكيد على أهمية استخدام مو اد البناء المحلية لكل منطقة و إعادة تشكيلها بما يو اكب النظور ات في مجال العمارة الداخلية. ج- ضرورة إحياء التكامل و الانسجام بين البيئة المحلية و العو امل المناخية المحيطة من

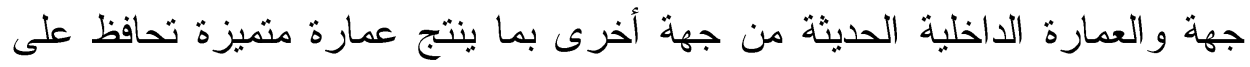
ثباتها ورسوخها وتحافظ على الطابع المحلي التقليدي من التذهور الحاصل بمرور الزمن. د- تحقيق تكنولوجيا التصميم المتوافقة واستخدام علوم العصر ومكتشفاته في نطوير العمارة الداخلية ، وفق نظريات ميكانيكية التزبة و علوم مقاومة المو اد وطبيعة البناء من تهوية و إنارة وعزل حراري...الخ. فالتكنولوجيا المقصودة هي التي تُكون بيئة متو افقة، فمنى تو افقت العمارة مع العلوم الإنسانية والطبيعية فأنها تكون منقدمة

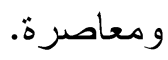


ه - تصميم عمارة داخلية معاصرة تتناسب مع المتغيرات وتتلاءم مع البيئة المحلية و العادات والثقاليد وتلبي كافة المنطلبات الإنسانية و الاجتماعية و الاقتصادية و الثقافية

$$
\text { و التاريخية. }
$$

مشاريع معمارية معاصرة إستلّهت عمار اتها الداخلية من التراث التقليدي لبعض مناطق

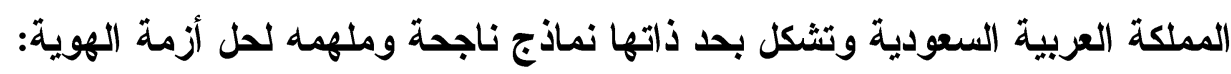

\section{أ-مشروع جامعة الملك فبصل بالأحساع و المستلهم من (طر از المنطقة الثرقبة):}

تقع جامعة الملك فيصل بالأحساء وهي إحدى المناطق الو اقعة ضمن نطاق المنطقة

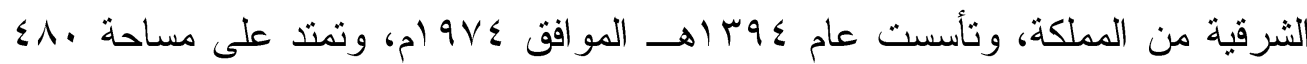

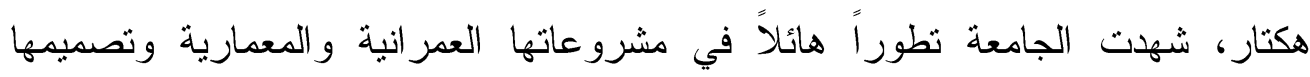
الداخلي جاءت على مر احل تتفيذية مختلفة لتلبي الاحتباجات المتلاحقة لزيادة عدد الملتحقين بالجامعة وتلبية لنطوير أساليب التعليم الحديثة. ويظهر من خلال تصميم مخططها مدى تلى الته

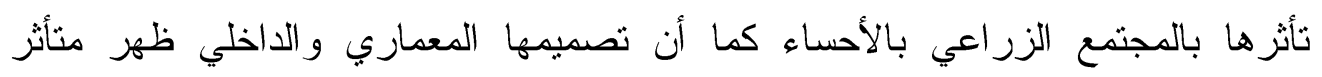

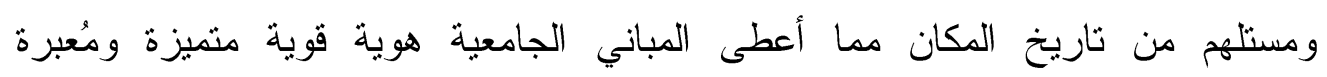

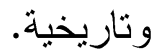

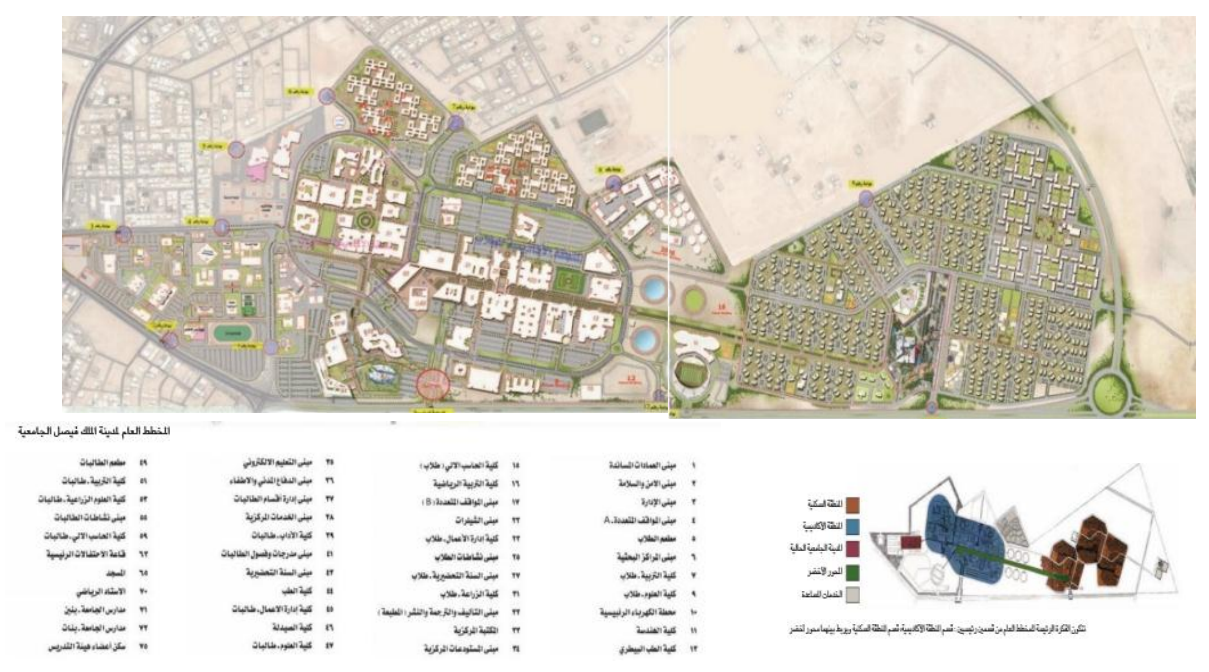

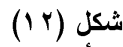

المخطط العام للمدينة الجامعية لجامعة المثك فيصل بالأحساء والمستوحى من ( طراز المنطقة الشرقية بالمملكة). 
روعي في تصميم مباني الجامعة أن تكون معبرة عن المستقبل من خلال تحقيق

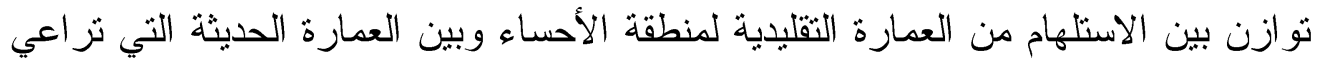

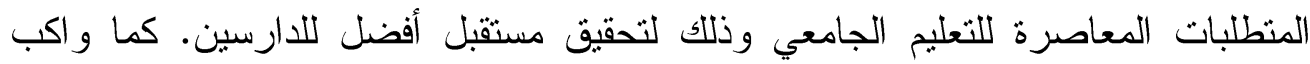
التصميم المعماري و الداخلي النطور التكنولوجي في شتى صوره وذللك بدوره حقق اقصى معاير الاستدامة للتصميم على المدى القريب و البعيد كما يعد التصميم إبداع انشائي مشحون فئي بالأرث الحضاري.

شكل (T) مساحات محيطة بالمباني. تُظهر تتسيق الموقع العام ومدى نأثر التصميم بالمجتمع الزر اعي بالأحساء وتثنكل فضاء

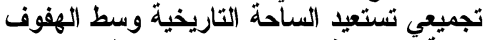

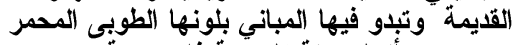
وكأنها مدينة تاريخية ذات هوية.

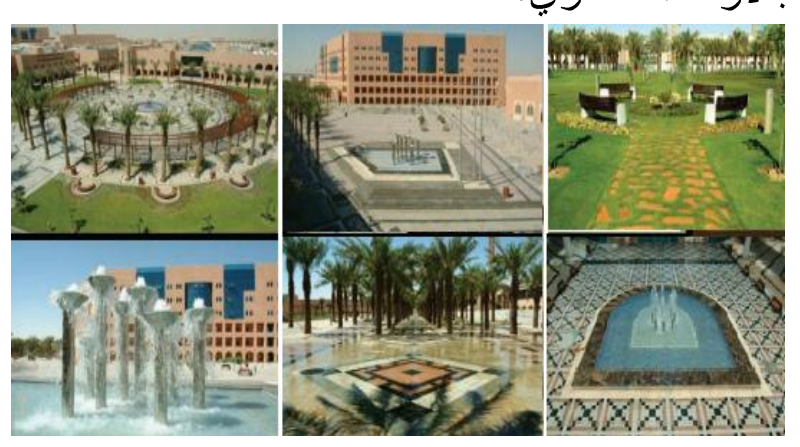

صمم مخطط الجامعة بحيث يحوي على بـ مبنى أكاديمي و اب مبنى خدمي وخمسة

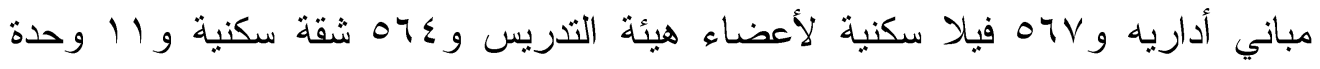

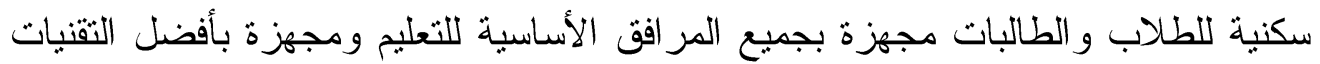
الحديثة إضافة الى المر افق التزفيهية و البيئية المختلفة. يقدم التصميم الداخلي لمباني الجامعة الفئل نوع من استعادة اللغة التاريخية على مستوى العناصر البصرية وهذا في حد ذاته يمثل

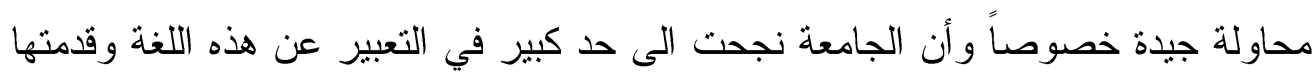
بشكل سهل وبسيط وهو ما يحسب لعمارة الجامعة.
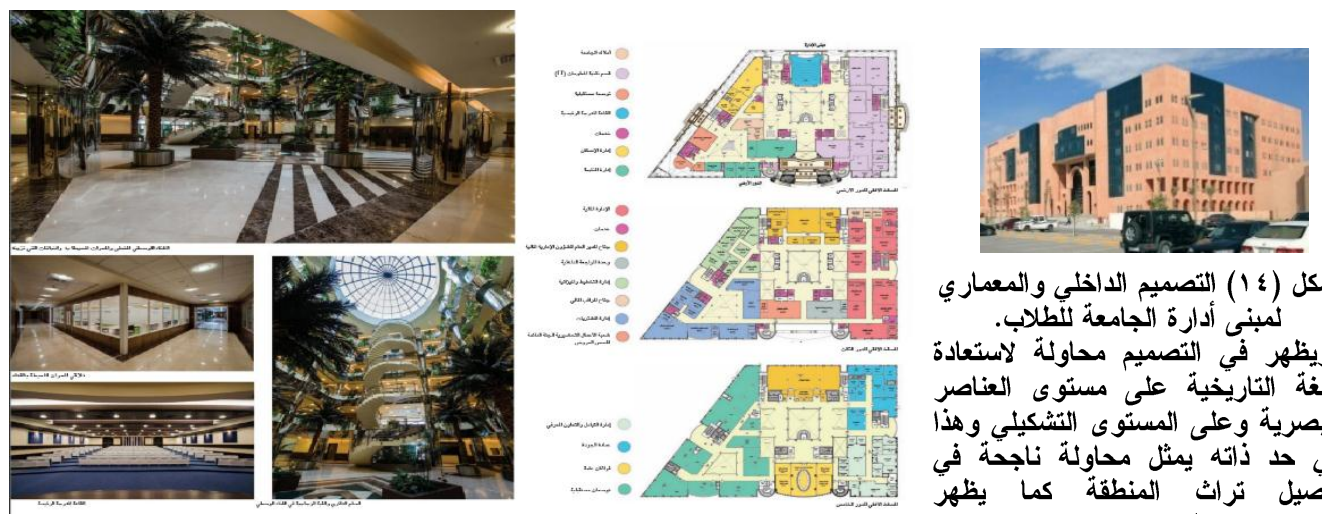

شكل (ع 1) التصميم الداخلي و المعماري

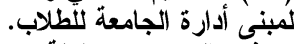

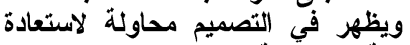
اللغة التاريخية على مستوى العناصر البصرية وعلى المستوى التثكيلي وهذا لفئل

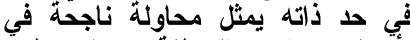

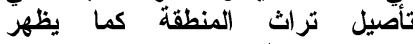
بالتصميم توظيف لتقنيات وتكنولوجيا 
شكل (0 1) التصميم اللاخلي

و والمعماري للمسجدا.

روعي في تصميمه الاستفادة من

أحلث الأساليب و الإمكانيات التصميمة التصنة

ومن عناصر العمارة الإسلامية، ويعد

تصميمه محاولة ناجحة لاسترجاع لألئي الهويةً المعمارية التي بدأت تثتلاشىى

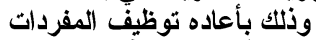

التصميمية للمساجد آنذاك و والمتو (فقة

مي البيئة في أطار معاصر.

شكل (4 إمبنى العمادات المساندة بجامعة الملثك فيصل.

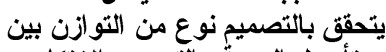

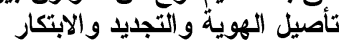

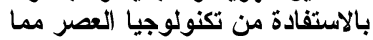
يحقى معادلة بين الثكل و والمضمون وبين الجمال والمنفعة في التصميل. حيث يظهر من خلال التصنميم تجاوبي

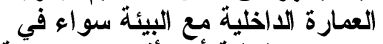
الحلول التخطيطية أو الأفكار التصميمية التوانية

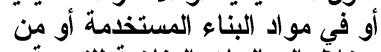
خلال المعالجات المناخية للتهوية المية بنوعيها وللإضاءة الطبيعية بالنهار.
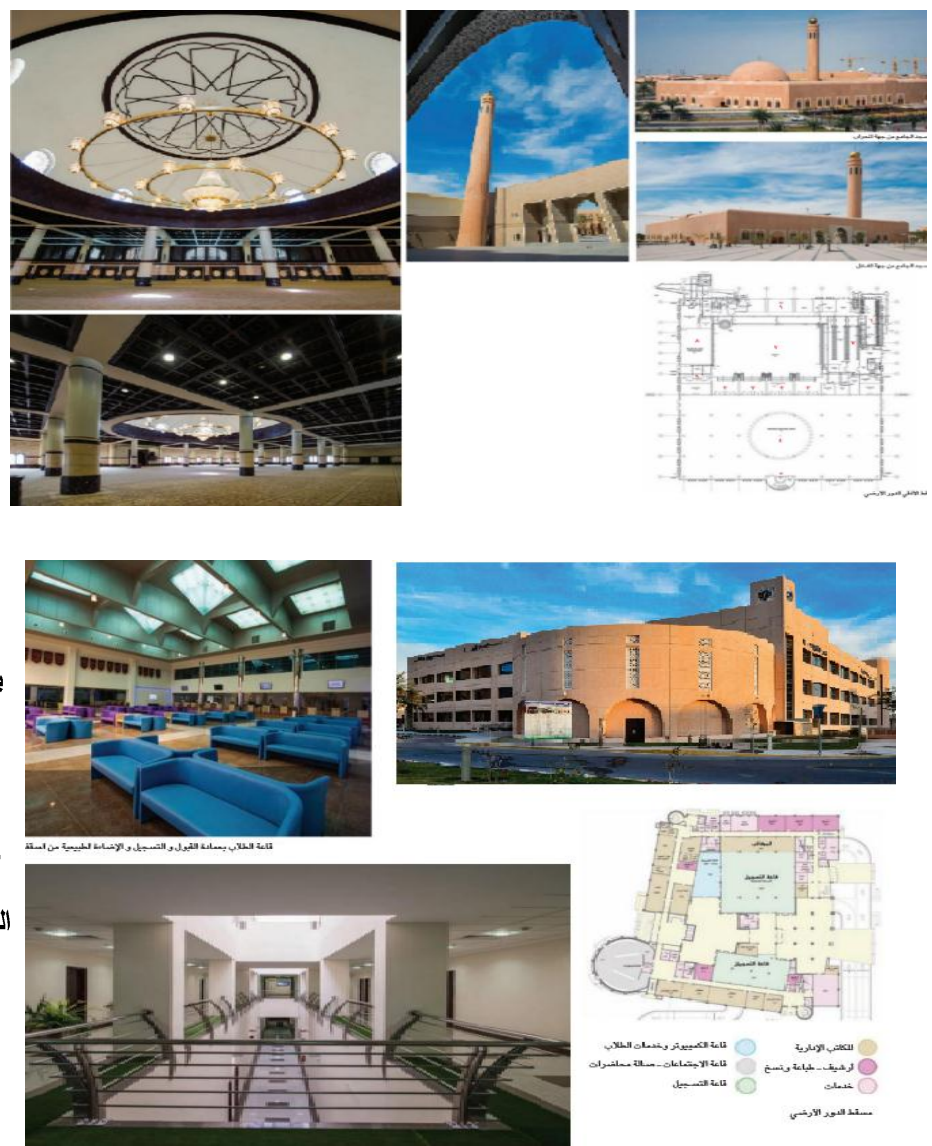

شكل (IV) كلية أدارة الأعمال للطلاب بالجامعة.

يظهر في تصميم العمارة الداخلية المبنى منهجية التصميم البيئي المعاصر المستمدة من روح التراث التقليدي بالأحساء حيث تم تتاول فكرة الرمزية في التصميم ببساطة تلاطية

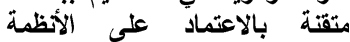
التكنولوجية المختلفة للوصول التطبل

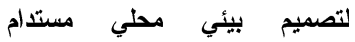
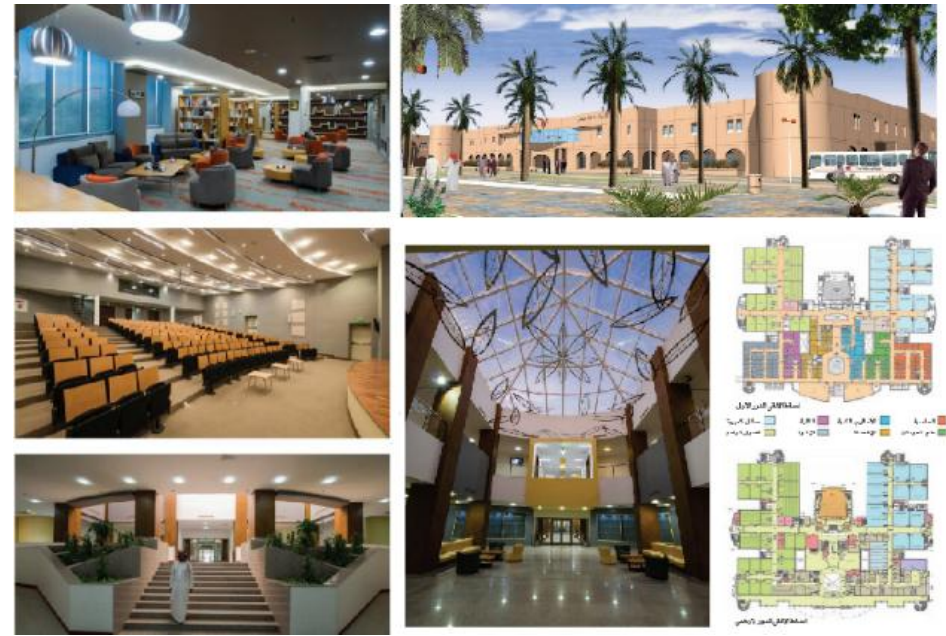

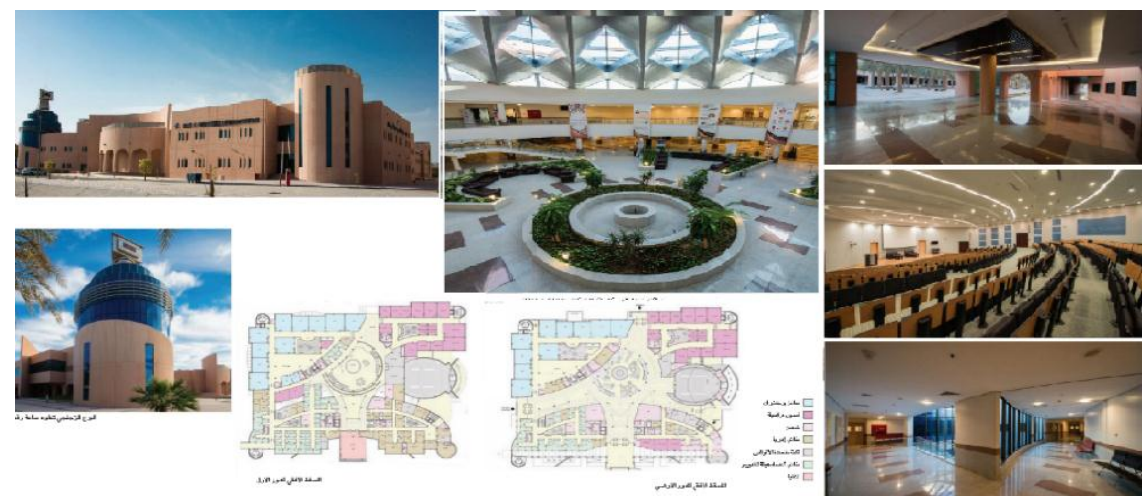

شكل (1^) كلية علوم الحاسب وتقنية المعلومات طلاب.

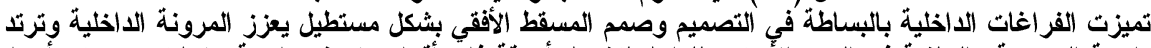

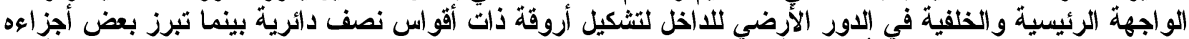

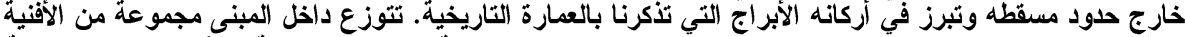

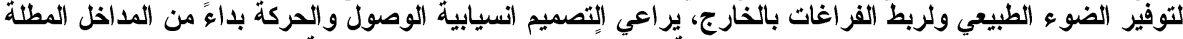

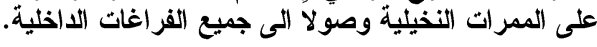

شكل (9 9 (1) أدارة أقسام (لطالبات بالجامعة. يعتمد التصميم الأخلي على الاستنغلأل الأمثل

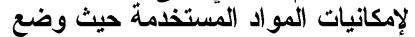

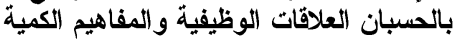

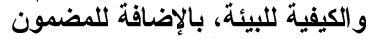

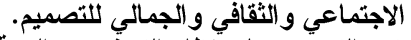

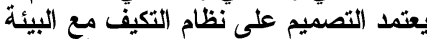

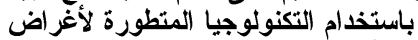

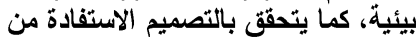

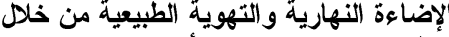

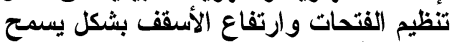
بحركة تيارات الهواء بشكل الأفل ميكانيكي.
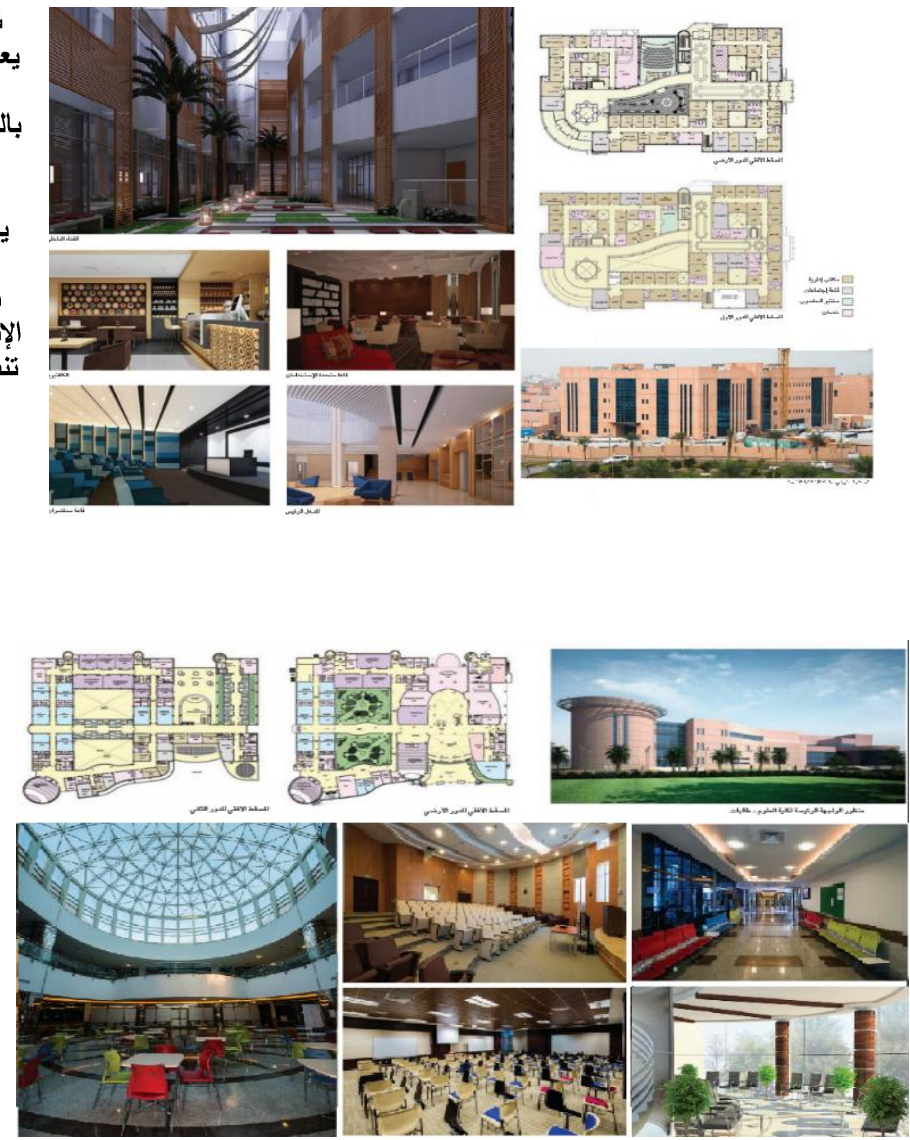
شكل (البا كلية التربية للطالبات.

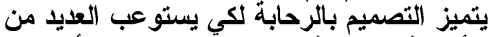
الأنشطة التعليمية التي تتكون من تعليم أكاديمي

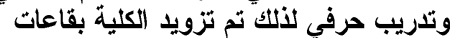

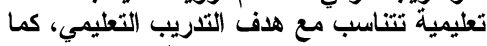

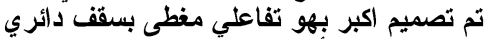
من الزجاج والألومنيوم على شكل ورئي وردة توحي

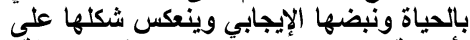

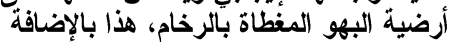
لرحابة الفصول وسهولة التو اصل بين الجميع.
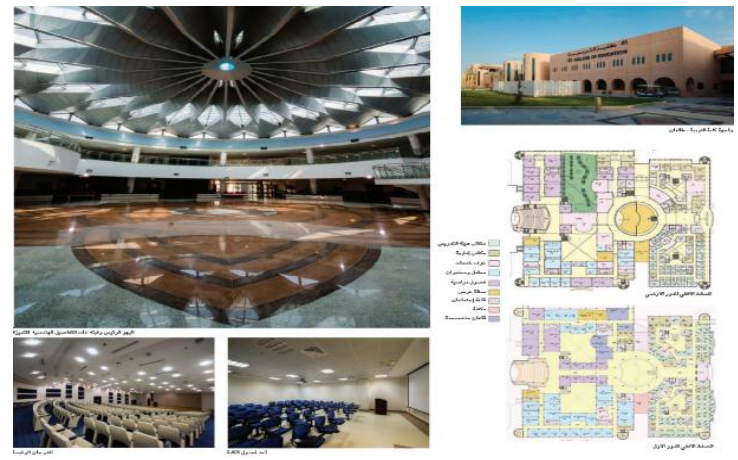

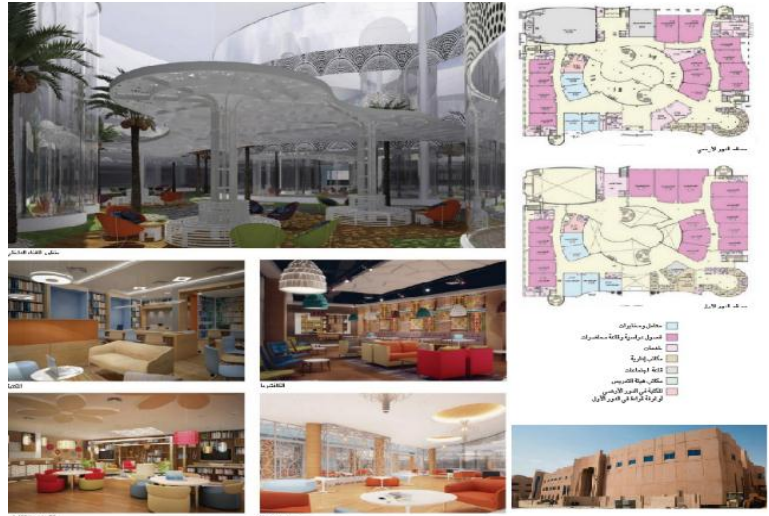

ب- مشروع جيل عمر بمكة

\section{المكرمة مستوحى من الطراز الحجازي (نمط المنطقة (الغريبة):}

يعد مشروع جبل عمر محاولة جادة لاسترجاع الهوية المعمارية التي بدأت تتلاشى ميطي

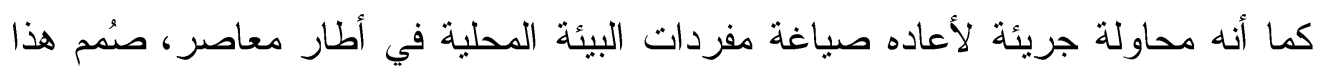
المشروع بطريقة حديثة تثو اكب مع التطور العمراني بالمنطقة وتُعبر عن أصالة وقدسية

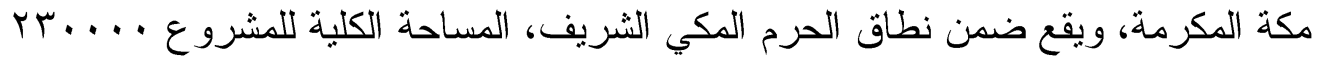
مثر مربع، ويحتوي على ابر اج فندقية واسواق تجارية ووحدات سكنبة وفنادق عالمية

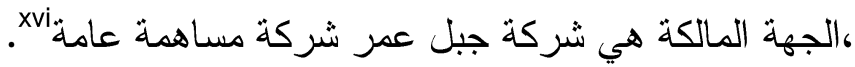



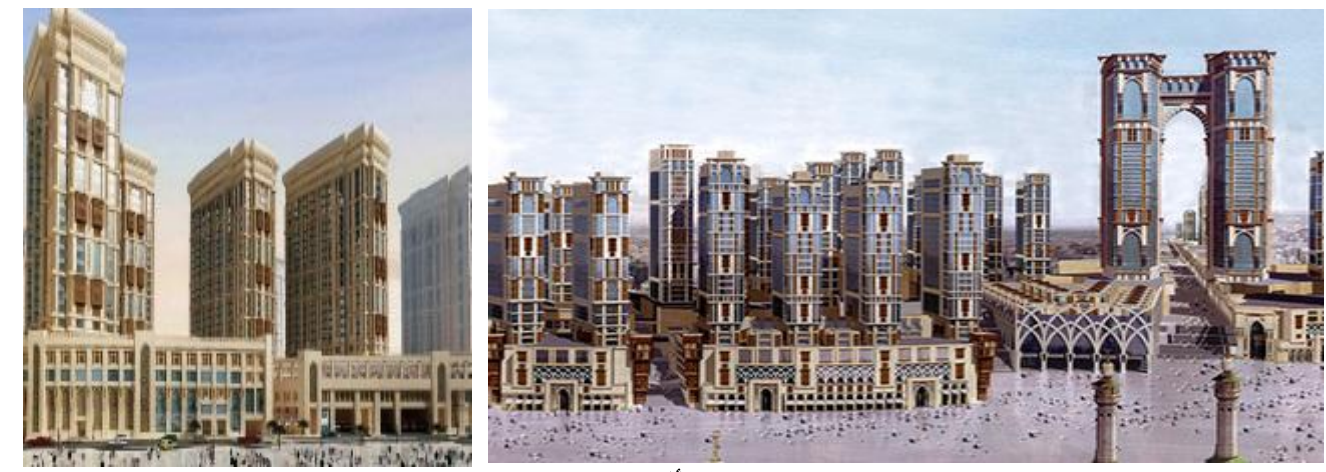

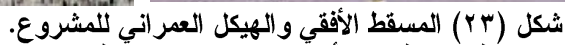

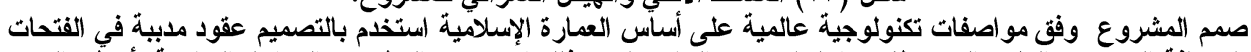
بالإضافة الى بعض العقود التي وظف بداخلها عنصر المشربيات، كذلك استخدمت المظلات والكو بلكوابيل الخشبية لأسطح المبنى واعلي الفتحات.
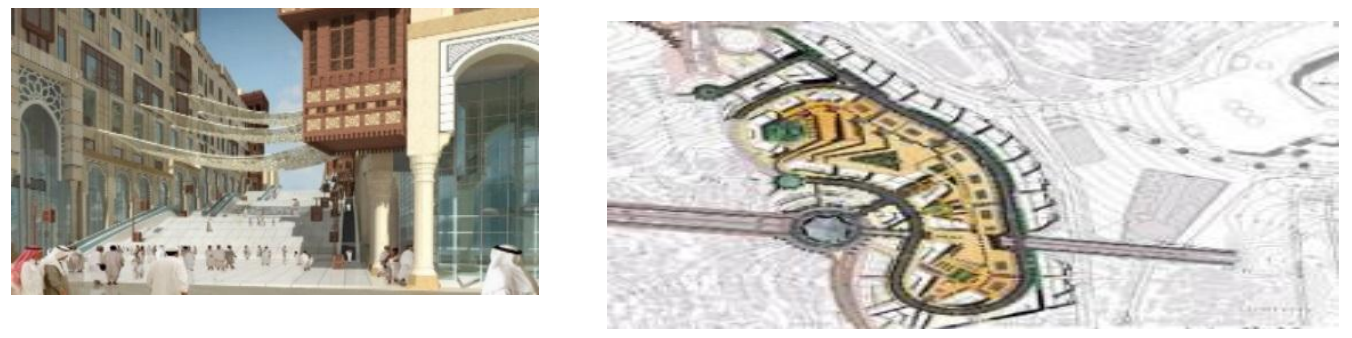

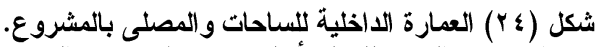

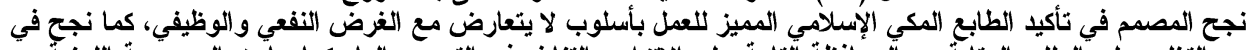

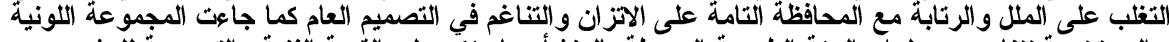

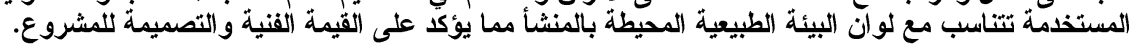
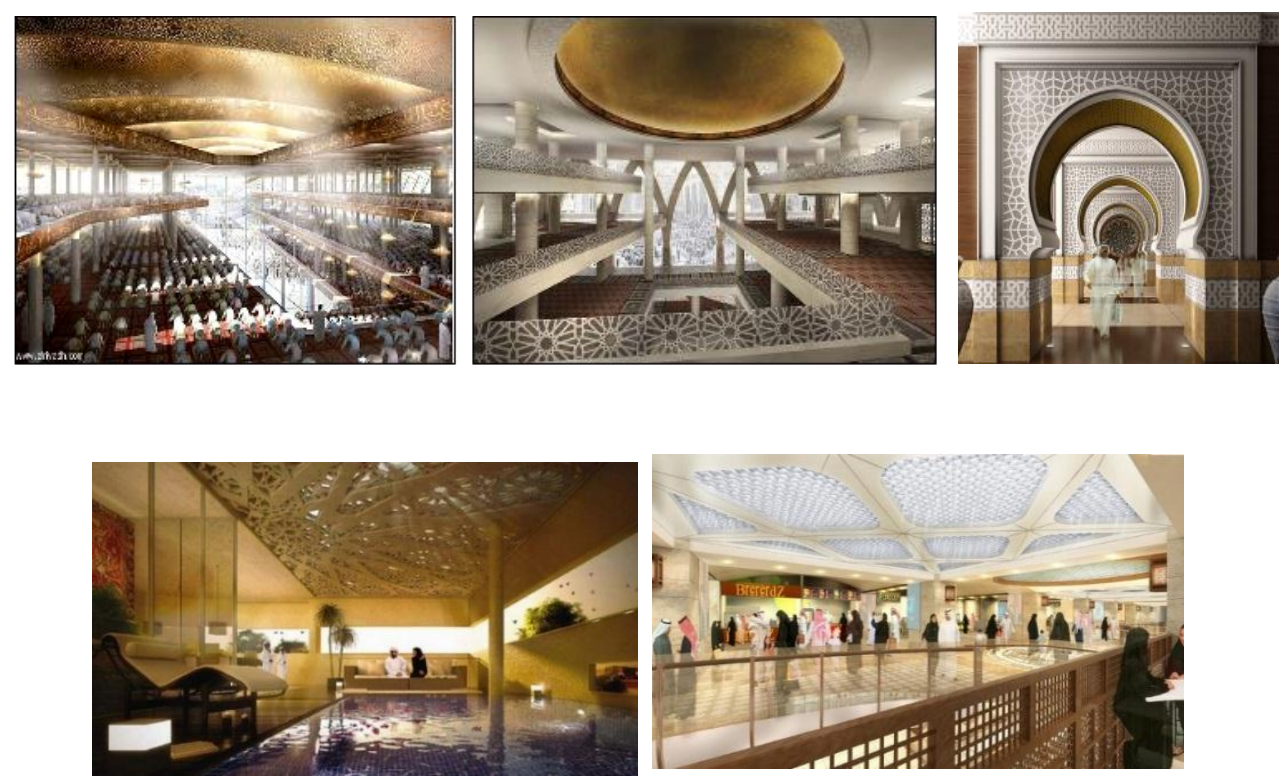

شكل (Yo) العمارة الادخلية لردهات المشروع و المركز التجاري.

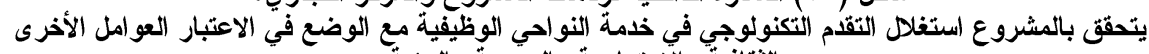
الثقافية والاجتماعية و الروحية و البيئية. 

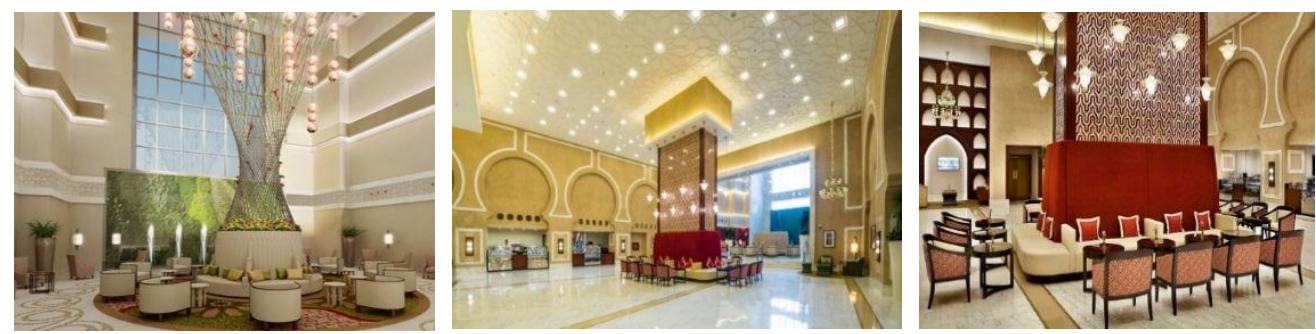

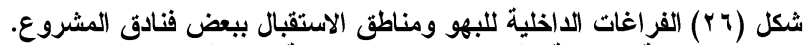

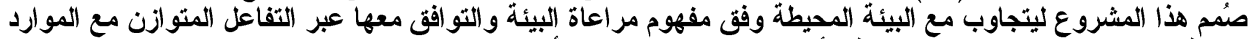

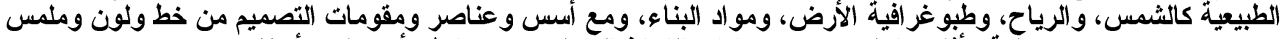

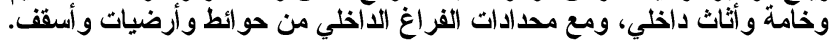
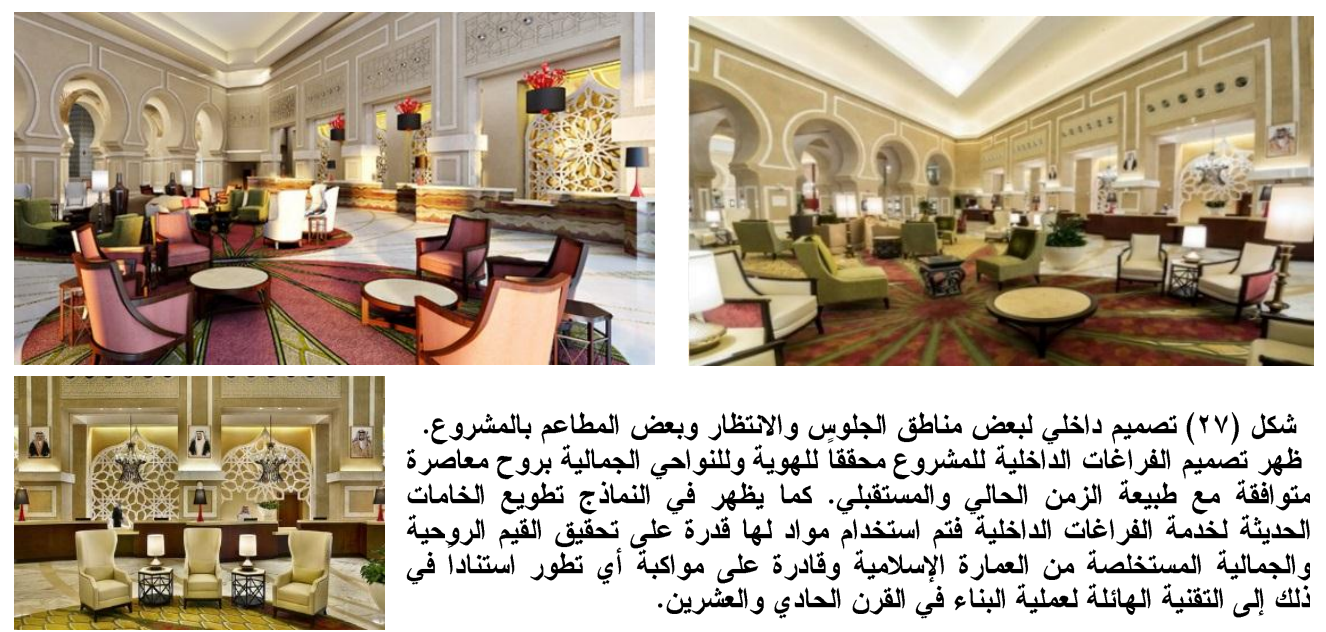

شكل (YV) تصميم داخلي لبعض مناطق الجلوسِ والانتظار وبعض المطاعم بالمشروع.

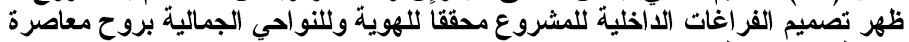

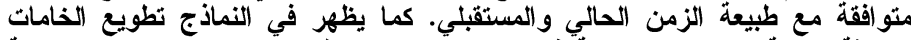

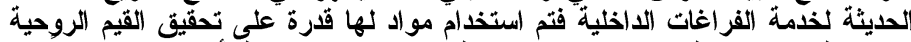

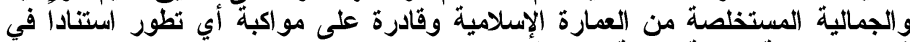

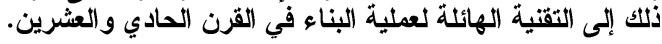
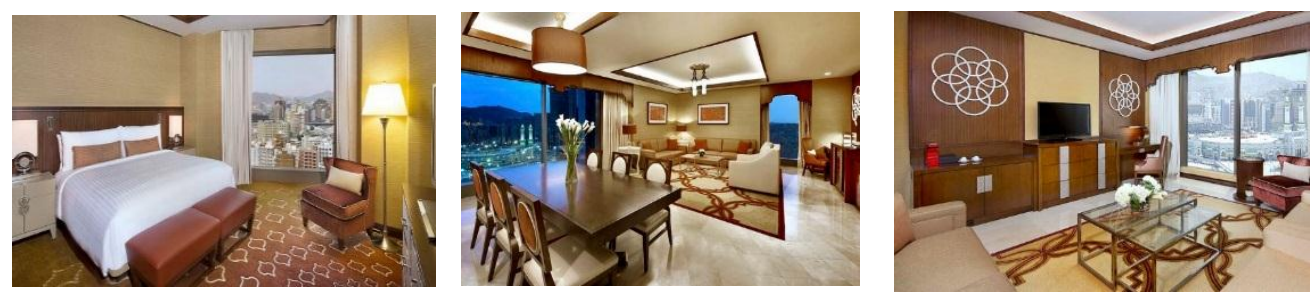

شكل (YN) أجنحة غرفٍ النوم بأحد الفنادق بالمشروع.

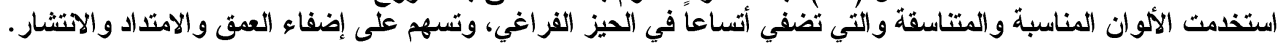

ج- مشروع مجمي الاقنيوز الرياض (نمط المنطقة الوسطى):

يصنف هذا المشروع ضمن أحد أكبر المجمعات في الثرق الأوسط، اقيم بمدينة الرياض

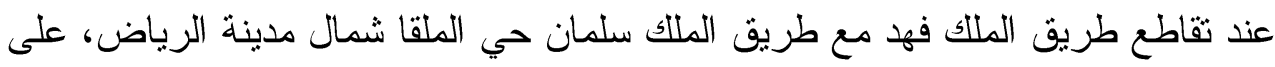


أرض مساحتها (9 ألف مثر مربع، المالك مجموعة الثايع الكويتية و المنفذ شركة شمول

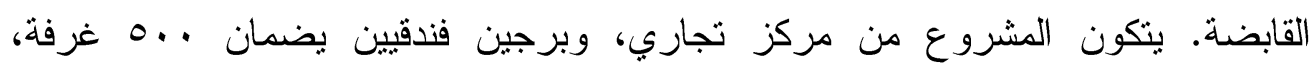

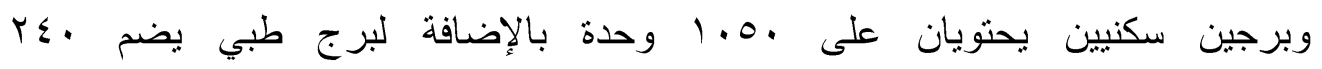
عيادة.xvii. استخدام المفردات التاريخية في التعبير وبعض العناصر المنتمية للعمارة المحلية وهو أحد اتجاهات عمارة ما بعد الحداثة.
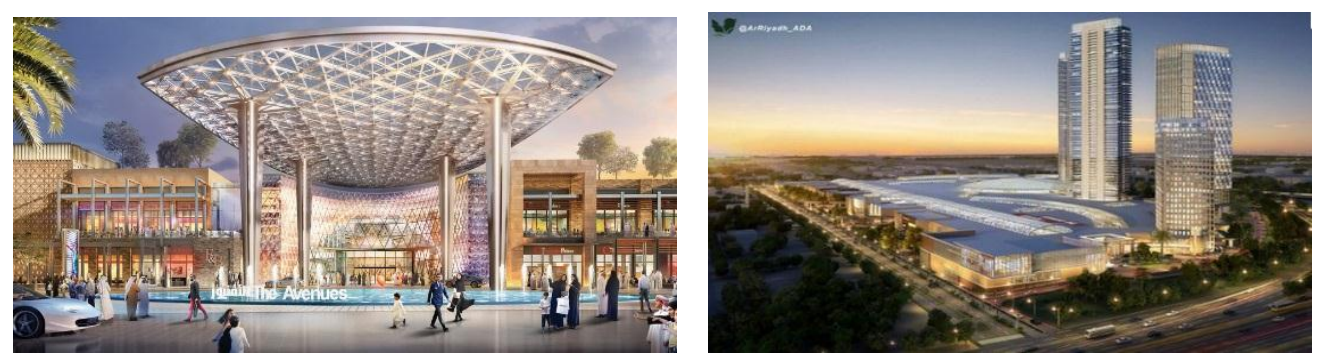

شكل (Y Y) منظر خارجي يوضح التصميم المعماري للمشروع وأحد المداخل الرئيسية له.

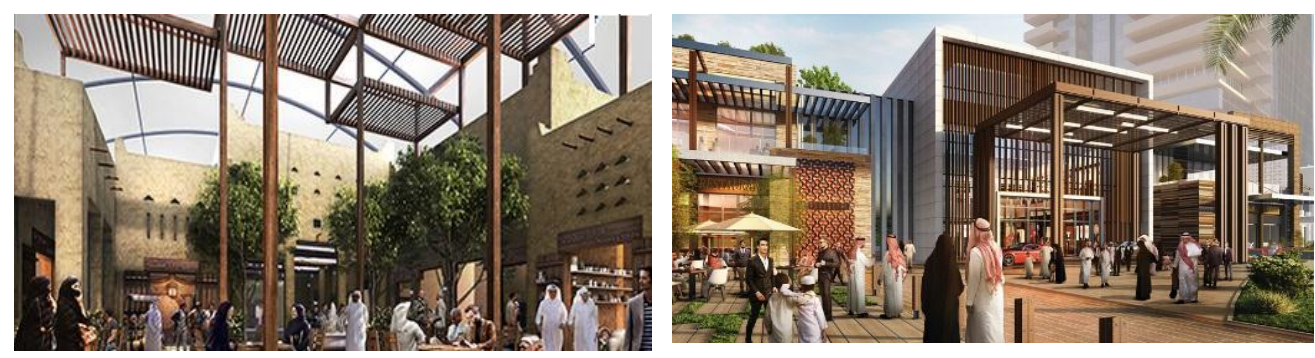

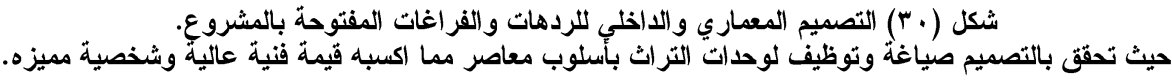
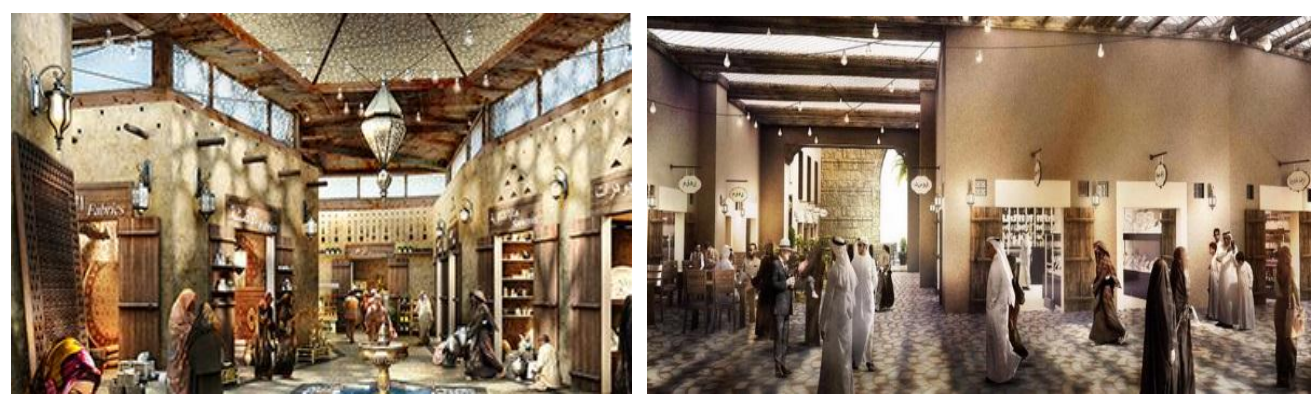

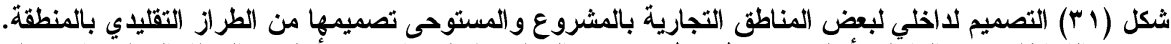

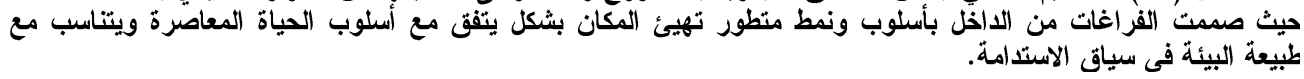




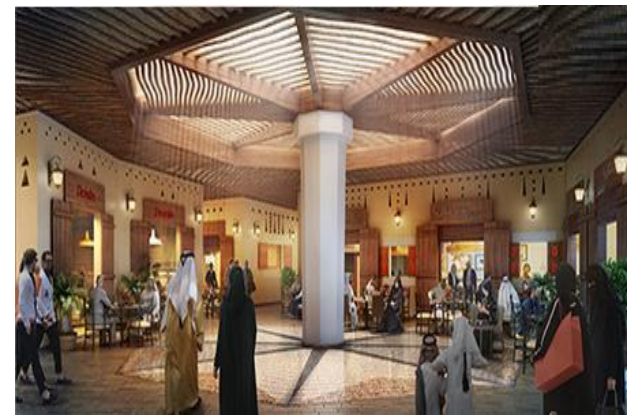

شكل (Y Y التصميم الاخلي لبعض مناطق الترفيه.

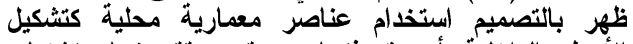

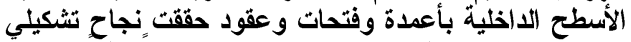

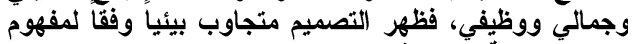

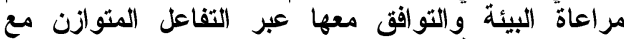

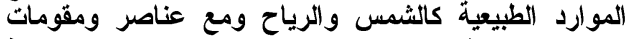

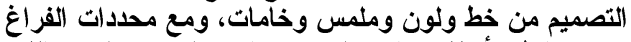

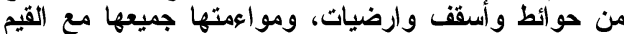
الاجتماعية وعادات واتقاليد المنطقة وسماتها الحضارية ي الثراثية.
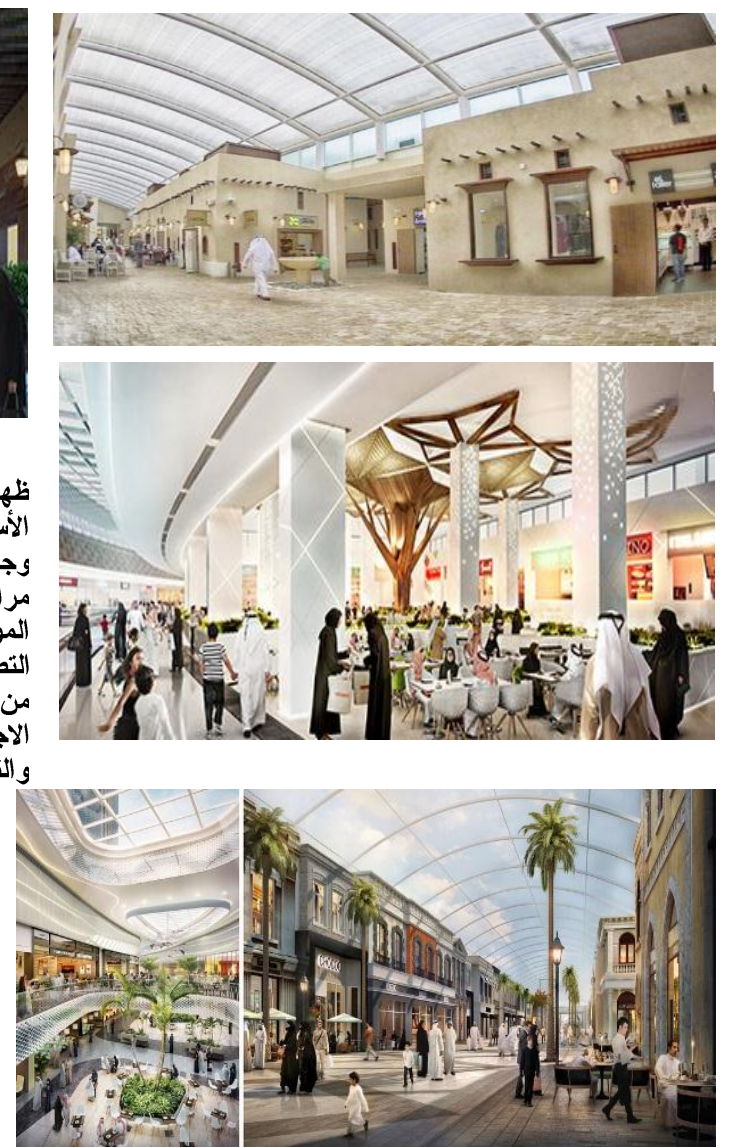

شكل (rr) التصميم الأاخلي للمول التجارِي بالمشروع.

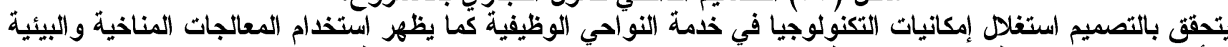

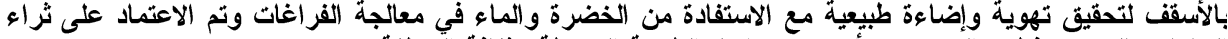

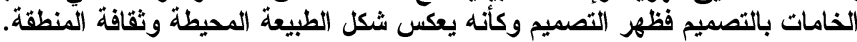
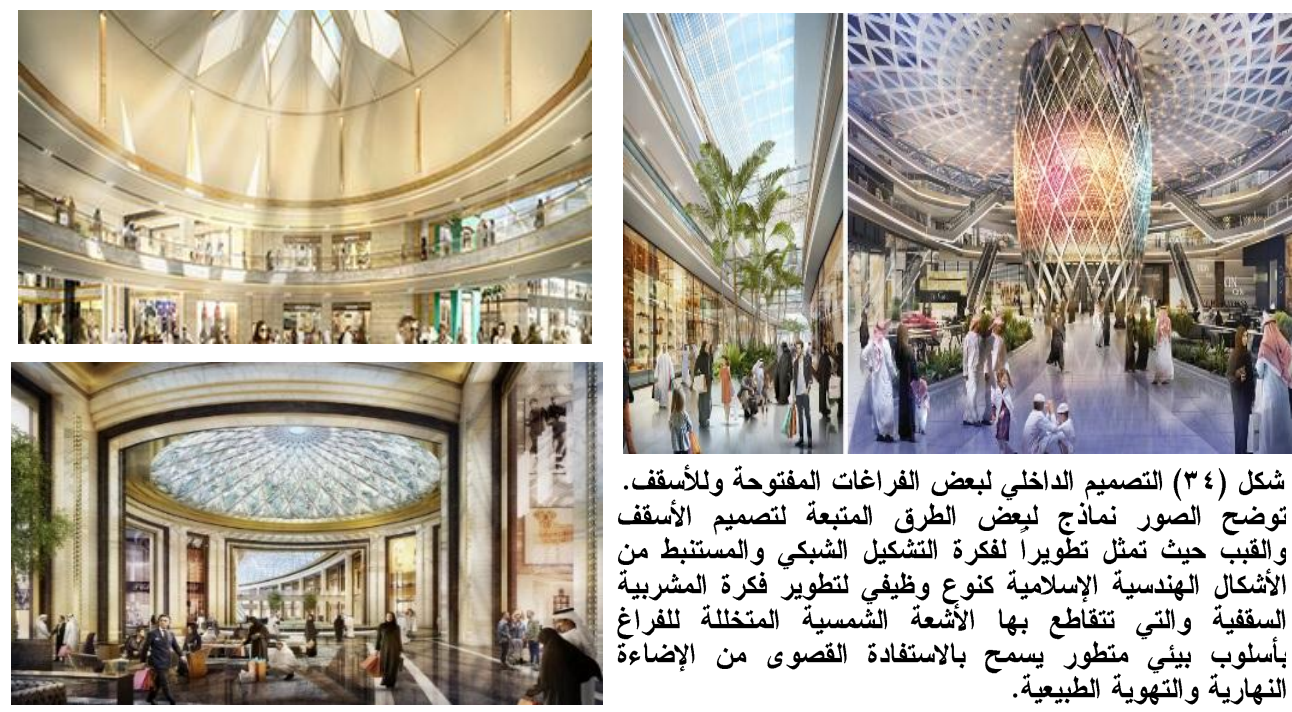

شكل (؟ ب) التصميم الاخلي لبعض الفر اغات المفتوحة وللأسقف.

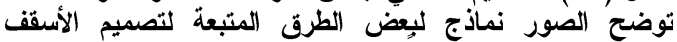

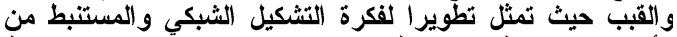
الأثكال الهندسية الإسلامية كنوع وظيفي لتطوئ لتطير فكرة المشربية

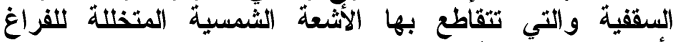
بأسلوب بئئي منطور يسمح بالاستفادة القصوى من الإضاءة النهارية و التهوية الطبيعية. 


\section{نتائج البحث:}

1. أسهمت طفرة النفط بالمملكة الى أحداث نهضة اقتصادية وعمر انية اثرت على هوية البيئة فأكسبتها تغييرات اجتماعبة وثقافية انعكست بشكل ملحوظ على هوية العمارة الداخلية اليوم.

r. من نتائج أزمة الهوية في العمارة الداخلية السعودية المعاصرة التأثر بالثقافات الغربية و الضعف الفكري المتمثل في التقليد و النقل عن الغير بدون دراسة متأنبة تتيح تتقية و أخذ ما يناسب قيمنا واخلاقياتتا وقو اعد الذوق التي تميزنا ورفض مانس ما لا يناسب.

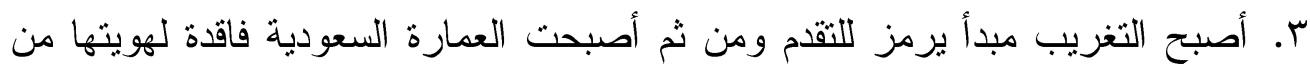
خلال فقدانها لمقوماتها النابعة من القيم الإسلامية والمعبرة عن البيئة الطبيعية و الاجتماعية.

ء. التو اصل بين التراث و المعاصرة يعطي النتاج التصميمي للعمارة الداخلية قيمة تعبيرية

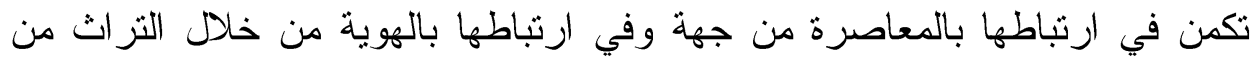

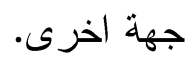

ه. أن افتقار تصميماتتا المعاصرة الى الأصول و الجذور التزاثية أدى الى اضطر اب في و اقع هويتتا والى تتاظر شديد بين الانسان و الفر اغ الذي نعيشه شكلاً ومضموناً.

توصيات البحث:

1. أعادة صياغة الهوية التزاثية المادية التشكيلية والتكوينية بروح تتناسب مع تكنولوجيا وروح العصر لتحقيق استدامة للعمارة الداخلية السعودية المعاصرة اليوم.

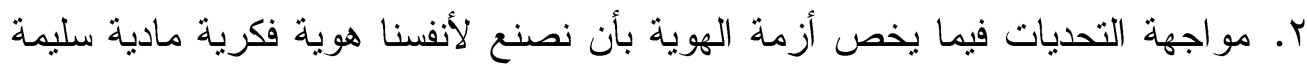
نتوصل من خلالها لعمارة داخلية محلية تتنمي الى المكان وتو اكب الزمان ذات لهديه خصوصية.

r. يوصي البحث بضرورة تحقيق موازنة بين المؤثرات الموروثة والوافدة علينا

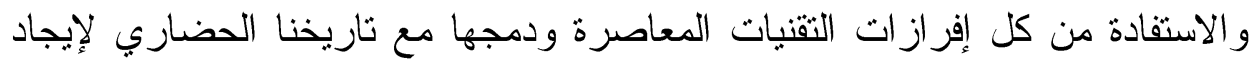
هوية لعمارتتا الداخلية. ء. غربلة عناصر التزاث المعماري السعودي بما يحتويه من فلسفة ومضمون وشكل ووظيفة وتوظيف ما يصلح منه في العمارة الداخلية المعاصرة تأكيداً لهويتتا. 
ه. نشر الوعي الثقافي وتعاون الأجهزة المسئولة من أجل توعية المجتمع بأهمية الانتماء

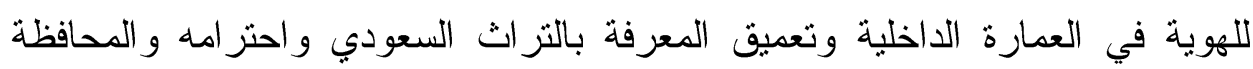
عليه وتأصيله. Ү. وضع إطار للوصول الى نماذج تفاعلية لتوثيق التزاث الثقليدي للعمارة الداخلية رقمباً حتى يسهل استعر اضه عن بعد والتعرف على عناصره ومكوناته نصياً وسمعياً

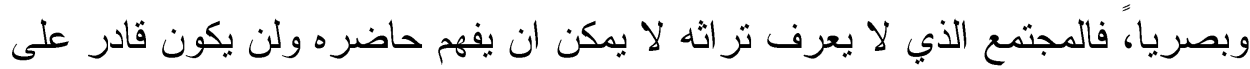
تحديد وقيادة مستقبله. 
الكتب والأبحاث:

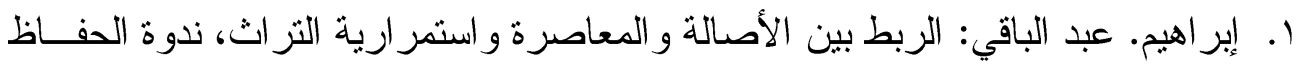

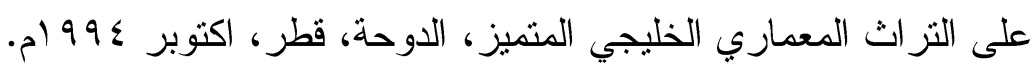

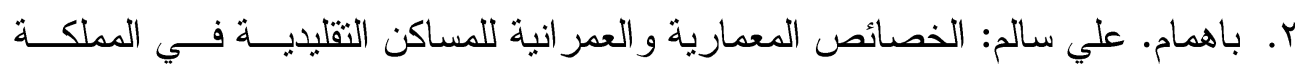

العربية السعودية، ورقة علمية المؤتمر العلمي الأول (العمارة الطينية على بوابة القرن

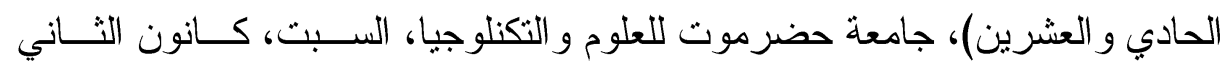

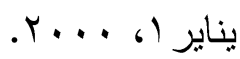

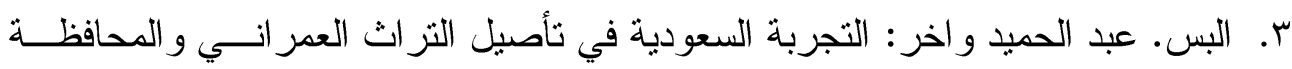

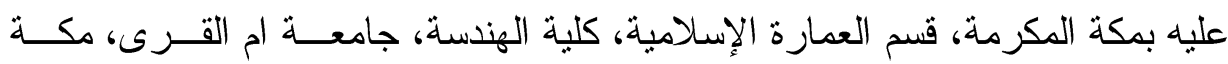

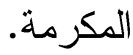

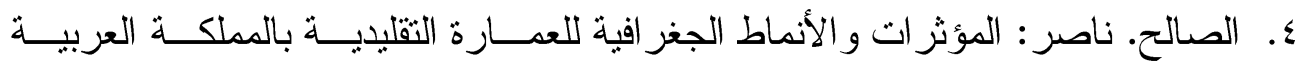

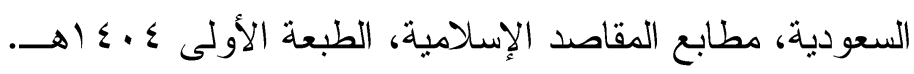

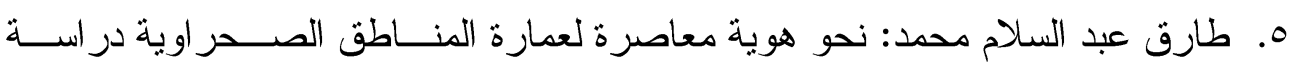

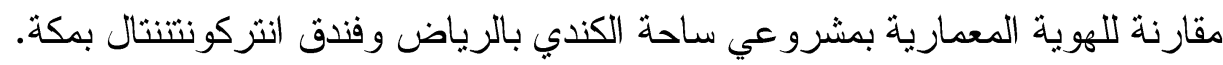

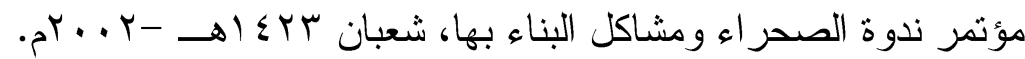

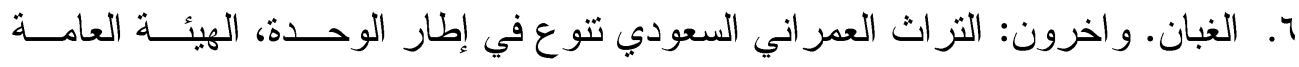

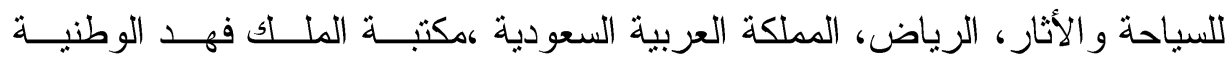
. $\rightarrow \leqslant$

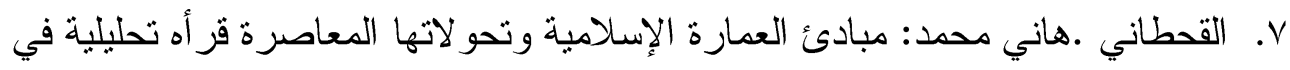

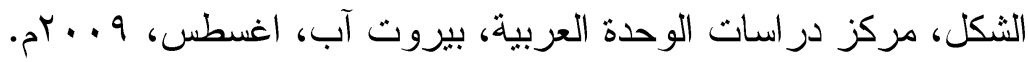

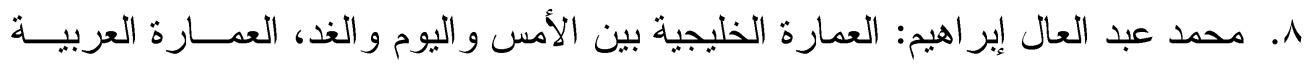

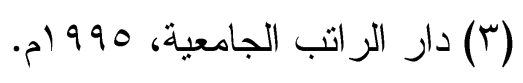

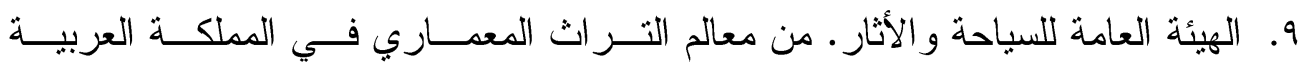

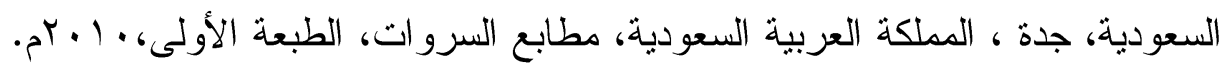




\section{المقالات من دوريات:}

• 1. الجليدي. نداء عامر." تطور الطرز الفنية في العمارة السعودية وتباينها في أربع

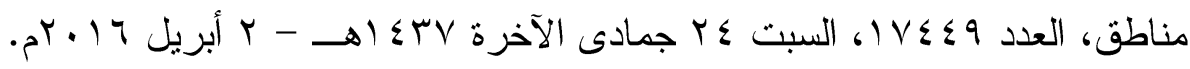

الـ السيد. وليد: الأصالة و المعاصرة و إثكالية العمارة العربية بين الماضي و الحاضر،

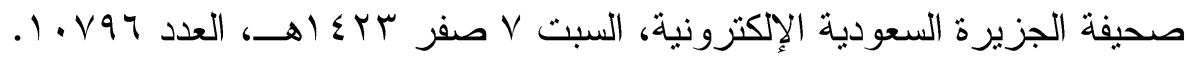

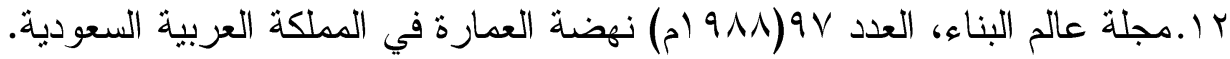
با ـششاري عبد الله النعيم: تحولات الهوية العمر انية، ثنائية الثقافة و التاريخ في العمارة الخليجية المعاصرة، مجلة المستقبل العربي، العدد بحr يناير ا . . بم. ع ا.وزيري. يحي: الهوية و الطابع المعماري بين الشكل و المضمون، مقالة منشورة، مجلة

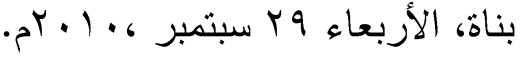

$$
\begin{aligned}
& \text { مواقع إلكترونبة: }
\end{aligned}
$$

1. الخندق. جهاد، الهوية المعمارية بين الوجود والضياع، العمارة والتاريخ،

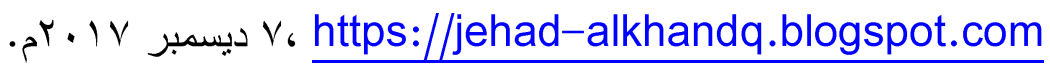
7 ا ـ مشاريع السعودية، 
